\section{E-LOGOS}

ELECTRONIC JOURNAL FOR PHILOSOPHY ISSN 1211-0442

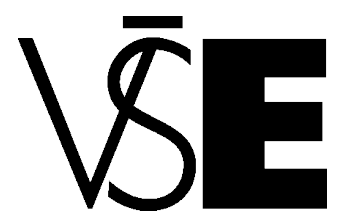

University of Economics

Prague

\title{
Dopis o nekonečnu
}

(nový český překlad Spinozova dopisu L. Meyerovi z dubna 1663) ${ }^{1}$

Martin Hemelík

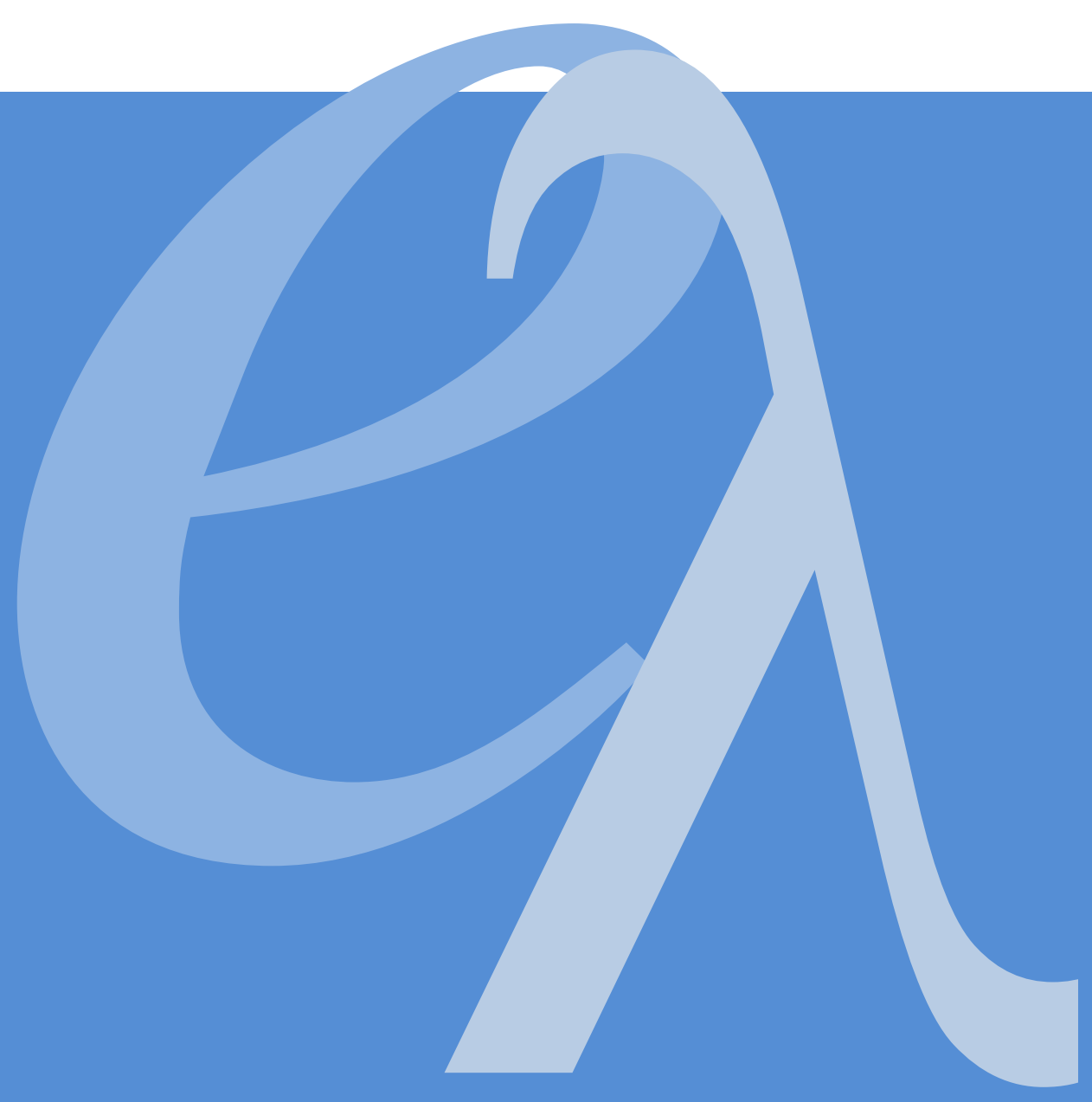




\begin{abstract}
This paper contains new translation (the first and till to this time sole czech translation dates back to 1932) of one of important letters, which Dutch philosopher Baruch Benedict Spinoza (1632-1677) wrote in year 1663 to his friend Lodewijk Meyer. The fundamental subject of this letter is Spinoza's understanding of concept of the infinite, which has very important position both in the mathematics and in the philosophy.
\end{abstract}

Keywords: The infinite - philosophy - mathematics - Spinoza - Meyer

\title{
Abstrakt
}

Tato stat' obsahuje novou verzi překladu (první a dosud jediný český překlad pochází z roku 1932) jednoho z významných dopisů, který napsal holandský filosof Baruch Benedictus Spinoza (1632-1677) svému př́teli Lodewijku Meyerovi v roce 1663. Základním tématem tohoto dopisu je Spinozovo pochopení pojmu nekonečna, kterému náleží velice důležítá role jak v matematice, tak ve filosofii.

Klíčová slova: Nekonečno - filosofie - matematika - Spinoza - Meyer 


\section{Několik slov úvodem}

Zabývat se myšlenkami starých filosofü, číst jejich texty, překládat je, interpretovat a komentovat - to vše může mít řadu více i méně vznešených důvodů a pohnutek, může tím být realizováno leccos, mohou se tak naplňovat nejrůznější cíle, leckteré úsilí může tak dosáhnout osmyslení. O tom všem je v současnosti hojně diskutováno, vedou se spory, rozvíjejí se polemiky a diskuse. Pro mne je velmi důležitým (ne-li nejdůležitějším) důvod, který bych si troufl označit jako „,věcně inspirativní“.

Žádný odpůrce všeho tzv. přežilého, či jakoby zastaralého, resp. ,,jen a pouze“ historického nemůže poprrít, že při fillosofické tematizaci otázek týkajících se světa a člověka v něm nemá časový (historický) rozměr př́liš velkou relevanci, protože filosofie v celé své tisícileté historii byla a je především kladením otázek a hledáním cest, po nichž se může lidské myšlení vydat. Ono hledání cest a klestění si možných průchodů spletitými houštinami lidské skutečnosti je neutuchajícím výrazem touhy po chápajícím poznání, touhy po porozumění, která spojovala vždy a stále spojuje lidské generace přes vzdálenost věků a historických dob.

V tomto smyslu lze prakticky každý z vážně a hluboce míněných lidských pokusů o porozumění považovat za inspirující a stojí za to mu věnovat pozornost, i když se to na první pohled $\mathrm{v}$ dnešní znuděné době toužící po neustálém vnějším vzrušení může zdát čímsi zdlouhavým, málo nebo nic nepřinášejícím, a proto zbytečným. Záleží ovšem na otevřenosti lidské mysli, na schopnosti podílet se na oné touze po porozumění, na odolnosti vůči současné všestravující nudě a tedy vnějškově zahlcujícím vzrušení, aby byl onen první pohled nahrazen, resp. nahrazován pohledy dalšími, v nichž se bude více a více ukazovat, že zvláště důkladné a pečlivě propracovávané pokusy o porozumění, at' vznikly v kterékoli době, mohou být nejen věcně zajímavé, ale především hluboce inspirující a posilující vnímavého lidského ducha v boji s anti-duchem, ${ }^{2}$ který prostřednictvím nudy pohlcuje lidskou současnost v kontextu evropského civilizačního okruhu.

Abych alespoň v krátkosti naznačil, $v$ jakém směru se tu a tam pokouším uplatnit a použít onen „věcně inspirující“ důvod, nově jsem přeložil a okomentoval slavný Spinozův „dopis o nekonečnu“ (epistula de infinito). Má volba padla právě na tento text proto, že jsem přesvědčen, že tematizace lidského pochopení (pokud je možno o něčem takovém mluvit) nekonečna má svůj nezastupitelný význam v úsilí o porozumění, at' se odehrává ve filosofii, matematice či jiném specializovaném oboru lidského vědění, ba troufám si tvrdit, že dokonce představuje jednu $\mathrm{z}$ conditiones sine qua non jakéhokoli takového úsilí v době dnešní i v dobách budoucích. 


\section{List $^{3}$ XII. ${ }^{4}$}

Muži nejučenějšímu a nejzkušenějšímu

Lodewijkovi Meyerovi,

doktoru filosofie a medicíny ${ }^{5}$

od

Benedikta de Spinozy

Vzácný př́iteli,

Obdržel jsem od tebe dva dopisy. Jeden datovaný 11 . ledna $\{1663\}^{6}$, který mi předal př́tel N.N. ${ }^{7}$, a druhý [datovaný] 26. března $\{1663\}^{8}$, který mi poslal jakýsi neznámý prrítel z Leidenu. Oba jsem velice uvítal zvláště pak proto, že jsem z nich vyrozuměl, že je u tebe vše v nejlepším pořádku a že na mne často vzpomínáš. Převelikými díky jsem ti pak zavázán za laskavou pozornost a čest, kterou jsi mi vždy považoval za vhodné prokazovat. Zároveň prosím, abys věřil, že i já jsem ti neméně oddán a že budu při každé prŕležitosti, pokud na to budou mé slabé síly stačit, usilovat to prokázat. A abych $\mathrm{s}$ tím hned začal, pokusím se odpovědět na to, nač se mne tážeš ve svých dopisech. Žádáš, abych ti sdělil, k čemu jsem dospěl při přemýšlení o nekonečnu. S největší radostí a ze srdce rád tak učiním. Otázka [po povaze] nekonečna se všem zdála vždy nesmírně obtížná, ba přímo neřešitelná /viz komentáŕ 1/ proto, že nerozlišovali mezi tím, co je nekonečné $\mathrm{v}$ důsledku své přirozenosti neboli čeho nekonečnost vyplývá $\mathrm{Z}$ významu jeho definice, a tím, co nemá žádné hranice, nikoli však z moci své esence, nýbrž silou své prríčiny /viz komentár $2 /$. A rovněž proto, že nerozlišovali mezi tím, co se nazývá nekonečným, protože nemá konce, a tím, čeho části, ačkoli máme jeho maximum a minimum, přece nemůžeme [adekvátně] vyjádřit nějakým číslem a tím [to] vysvětlit /viz komentáŕ 3/. Konečně pak proto, že nerozlišovali mezi tím, co můžeme pouze chápat, nikoli však si představit, a tím, co si také můžeme představit /viz komentár $4 /$. Kdyby si na mou věru na to dávali pozor, nikdy by se
Epistola XII.

Viro doctissimo, atque Expertissimo Ludovico Meyer P.M.Q.D. B. d. S.

\{Van de natuur van 't Oneindig. $\left.{ }^{9}\right\}$

Amice singularis,

Duas abs te accepi Epistolas, unam die 11 Januari \{1663.\} datam, \& ab amico N.N. mihi traditam, alteram verò 26 die Martii \{1663\}, \& ab amico, nescio quo, Leidâ missam. Pergratce mihi amboe fuerunt; procipuè, ubi ex iis, omnia tua optimè se habere, neque mei scepe memorem intellexi. Porrò pro tuâ erga me humanitate, \& honore, quo semper me dignatus es afficere, maximas, quas debeo, ago gratias; simulque precor, ut me tibi non minùs addictum credas, quod semper datâ occasione, quantùm mea ferre poterit tenuitas, ostendere conabor. Atque hoc ut incipiam, ad id, quod in tuis Epistolis ex me quoeris, respondere curabo. Petis autem, ut, quae de Infinito excogitata habeam, tibi communicem, quod libentissimè faciam.

Qucestio de Infinito omnibus semper difficillima, imò inextricabilis visa fuit, propterea quòd non distinxerunt ${ }^{10}$ inter id, quod suâ naturâ, sive vi suce definitionis sequitur esse infinitum; \& id, quod nullo fines habet, non quidem vi suce essentice; sed vi suce causce. Ac etiam, quia non distinxerunt inter id, quod infinitum dicitur, quia nullo habet fines; \& id, cujus partes, quamvis ejus maximum \& minimum habeamus, ${ }^{11}$ nullo tamen numero adcequare, \& explicare possumus. Denique quia non distinxerunt inter id, quod solummodò intelligere, non verò imaginari; \& inter id, quod etiam imaginari possumus. Ad hoec, inquam, si attendissent, nunquam tam ingenii difficultatum turbâ obruti fuissent. Clarè enim tum intellexissent, quale Infinitum in nullas partes dividi, seu 
neocitli v tak ohromných potížích. Jasně by totiž chápali, které nekonečno nemůže být děleno do částí neboli které nekonečno nemůže mít části a u kterého [nekonečna] je to naopak možné bez rozporu. Dále by také pochopili, které nekonečno může být bez jakéhokoli zmatení pochopeno jako větší než jiné nekonečno a které nikoli. /viz komentár 5 / To vše se jasně vyjeví z toho, co vzápětí vyložím.

Dřive však vyložím několika slovy tuto čtveřici [pojmů], tj. substanci, modus, věčnost a trvání. Co se týče substance, chtěl bych, aby bylo uváženo následující: Zaprvé že k její esenci náleží existence, tj. že ze samotné její esence a definice plyne, že existuje, což jsem ti, pokud mne pamět' neklame, dř́ve dokázal ústně a bez pomoci jiných tvrzení. Zadruhé (což plyne $\mathrm{z}$ prvého) že substance téže přirozenosti neexistuje mnohonásobná, ale nanejvýš jedna jediná. Konečně zatřetí že každá substance musí být chápána jako nekonečná. Stavy substance pak nazývám mody, jejichž definice, pokud to není sama definice substance, nemůže zahrnovat žádnou existenci. Pročež, ačkoli existují, můžeme je pojímat jako neexistující. $Z$ toho dále plyne, že přihlížíme-li $\mathrm{k}$ samotné esenci modů a nikoli $\mathrm{k}$ řádu celé prŕrody, nemůžeme z toho, že již existují, vyvozovat, že samy budou později existovat nebo neexistovat, nebo že dřive existovaly nebo neexistovaly. /viz komentár 6 / Z toho jasně vyplývá, že existenci substance po všech stránkách pojímáme jako rozdílnou od existence modů. Odtud pochází rozdíl mezi věčností a trváním. Trváním totiž můžeme vysvětlit pouze existenci modů, [existenci] substance pak věčností, tj. nekonečným potěšením z existování neboli bytí (což je výraz odporující latinskému jazyku ${ }^{12}$ ). /viz komentár 71

Z toho všeho je jasné, že existenci a trvání modi̊, pokud přihlížíme, jak se převelice často stává, $\mathrm{k}$ jejich samotné esenci a nikoli $\mathrm{k}$ řádu prrírody, můžeme libovolně vymezovat, pojímat jako větší a menší a nullas partes habere potest; quale verò contrà, idque sine contradictione. Porrò etiam intellexissent, quale Infinitum majus alio Infinito sine ullâ implicantiâ; quale verò non item concipi potest; quod ex mox dicendis clarè apparebit. ${ }^{13}$

Verùm prius quatuor paucis exponam, videlicet $^{14} \quad$ Substantiam, Modum, Aternitatem, ${ }^{15}$ \& Durationem. Quce circa Substantiam considerari velim, sunt. Primò Quòd ad ejus essentiam pertinet existentia, hoc est, quòd ex solâ ejus essentiâ, \& definitione sequatur eam existere; quod, nisi me mea fallit memoria, antehac tibi vivâ voce absque ope aliarum Propositionum demonstravi. Secundum, \& quod ex hoc primo sequatur, est, quòd Substantia non multiplex; sed unica duntaxat ejusdem naturce existat. Tertium denique, quòd omnis Substantia non nisi infinita possit intelligi. Substantice verò Affectiones Modos voco, quorum definitio, quatenus non est ipsa Substantice definitio, nullam existentiam involvere potest. Quapropter, quamvis existant, eos ut non existentes concipere possumus; ex quo porrò sequatur, nos, ubi ad solam modorum essentiam; non verò ad ordinem totius Naturce $^{16}$ attendimus, non posse excludere ex eo, quòd jam existant, ipso postea exstituros, aut non exstituros, vel antea exstitisse, aut non exstitisse. Unde clarè apparet, nos existentiam Substantice toto genere à Modorum existentiâ diversam concipere. Ex quo oritur differentia inter Eternitatem, \& Durationem; per Durationem enim Modorum tantum existentiam explicare possumus; Substantice verò per Aternitatem, hoc est, infinitam existendi, sive, invitâ latinitate, essendi fruitionem.

Ex quibus omnibus clarè constat, nos Modorum existentiam \& Durationem, ubi, ut scepissime fit, ad solam eorum essentiam; non verò ad ordinem Naturce attendimus, ad libitum, \& quidem propterea nullatenus, quem eorum

habemus conceptum, destruendo, determinare, majorem minoremque 
dělit do částí a přitom tím nikterak nenarušíme pojem, který o nich máme.Věčnost však a substance, ježto se právě nemohou pojímat [jinak] než jako nekonečné, nemohou nic [takového] strpět. Tím bychom [totiž] zároveň narušili jejich pojem. /viz komentár 8 / Proto přímo žvaní, abych neříkal blouzní, ti, kteří mají za to, že rozlehlá substance je složena z částí neboli navzájem reálně odlišných těles. To je přesně stejné, jako kdyby se někdo snažil sestavit čtverec nebo trojúhelník nebo něco jiného bytostně rozdílného [od kruhu] pouhým přidáváním a hromaděním mnoha kruhů. Proto se každá taková hromada argumentů, kterými filosofové vesměs zamýšlejí ukázat, že je rozlehlá substance konečná, samovolně rozpadá. Všechny [tyto argumenty] totiž předpokládají, že ona tělesná substance je složena $\mathrm{z}$ částic. A stejným způsobem také jiní, když nabyli přesvědčení, že se přímka skládá z bodů, mohli odhalit mnohé argumenty, kterými by ukazovali, že př́mka není dělitelná do nekonečna. /viz komentár 9/

Tážeš-li se však, proč jsme tak přirozeně náchylní k rozdělování rozlehlé substance, pak na to odpovídám, že kvantitu pojímáme dvěma způsoby: totiž abstraktně neboli povrchně podle toho, jak ji máme s pomocí smyslů $\mathrm{v}$ představivosti, nebo jako substanci, což se odehrává pouze v rozumu. A tak tedy upínáme-li pozornost ke kvantitě podle toho, jak je $\mathrm{v}$ představivosti, což nastává snáze a co nejčastěji, shledáme ji dělitelnou, konečnou, složenou $\mathrm{z}$ částí a mnohonásobnou. Jestliže však upínáme pozornost k téže [kvantitě] podle toho, jak je v rozumu a věc se shledává, jak je o sobě, což se děje převelice obtížně, tak, jak \{pokud se nemýlím\} jsem ti dříve dostatečně dokázal, je [kvantita] shledána nekonečnou, nedělitelnou a jedinou. ${ }^{17} / v i z$ komentár $10 /$

Dále pokud tuto [kvantitu] pojímáme jako abstrahovanou od substance a oddělujeme ji od způsobu, kterým vyplývá $z$ věčných věcí, vzniká z toho čas a míra. Totiž čas concipere, atque in partes dividere posse: Aernitatem verò, \& Substantiam, quandoquidem non nisi infinitce concipi possunt, nihil eorum pati posse; nisi simul eorum conceptum destruamus. Quare ii prorsus garriunt, ne dicam insaniunt, qui Substantiam Extensam ex partibus, sive corporibus ab invicem realiter distinctis conflatam esse putant. Perinde enim est, ac si quis ex solâ additione, \& coacervatione multorum circulorum quadratum, aut triangulum, aut quid aliud, totâ essentiâ diversum, conflare studeat. Quare omnis illa farrago argumentorum, quibus Substantiam Extensam finitam esse ostendere Philosophi vulgò moliuntur, suâ sponte ruit: Omnia enim illa Substantiam corpoream ex partibus conflatam supponunt. Ad eundem etiam modum alii, qui postquam sibi persuaserunt, lineam ex punctis componi, multa invenire potuerunt argumenta, quibus ostenderent lineam non esse in infinitum divisibilem.

Si tamen quoras, cur naturce impulsu adeò propensi simus ad dividendam substantiam extensam: ad id respondeo, quòd quantitas duobus modis à nobis concipiatur; abstractè scilicet, sive superficialiter, prout ope sensuum eam in imaginatione habemus; vel ut substantia, quod non nisi à solo intellectu fit. Itaque si ad quantitatem, prout est in imaginatione, attendimus, quod sapissime, \& facilius fit, ea divisibilis, finita, ex partibus composita, \& multiplex ${ }^{18}$ reperietur. Sin ad eandem, prout est in intellectus, tum, ut \{, zo ik my niet vergis $\}^{19}$ satis antehac tibi demonstravi, infinita, indivisibilis, \& unica reperietur.

Porrò ex è̀, quòd Durationem \& Quantitatem pro libitu determinare possumus, ubi scilicet hanc à Substantiâ abstractam concipimus, \& illam à modo, quo à rebus aeternis fluit, separamus, oritur Tempus, \& Mensura; Tempus nempe ad Durationem; Mensura ad Quantitatem tali modo determinandam, ut, quoad fieri potest, eas facilè imaginemur. Deinde ex 
[ve vztahu] k trvání a míru [ve vztahu ke] kvantitě vymezujeme takovým způsobem, abychom si je, pokud je to možné, snadno představili. Dále z toho, že stavy substance oddělujeme od substance samotné a třídíme je tak, abychom si je, pokud je to možné, snadno představili, vzniká číslo, kterým je [tj. stavy] vymezujeme. $Z$ toho je jasně vidět, že míra, čas a číslo nejsou ničím [jiným] než mody myšlení, nebo spíše představování. /viz komentár $11 /$ Proto není nic udivujícího [na tom], že všichni, již usilovali [pomocí] podobných pojmů, navíc předtím špatně pochopených, o porozumění dějům prírody, se tak neobyčejně zamotali, že se nemohli vymotat jinak než obrácením všeho naruby a připuštěním [věcí] nesmyslných, ba [těch] nejnesmyslnějších. Nebot' jsou mnohé [pojmy], které nemůžeme nikdy postihnout představivostí, nýbrž pouze rozumem, jako je substance, věčnost a jiné. Jestliže se někdo snaží takové [věci] vysvětlit [pomocí] pojmů, které jsou toliko pomůckami představivosti, nedělá nic více, než že si se svou představivostí počíná jako blázen. Ani samotné mody substance, pokud jsou pomíchány $\mathrm{s}$ takovými pomyslnými jsoucny neboli pomůckami predstavivosti, nemohou být nikdy správně pochopeny. Nebot' když tak činíme, oddělujeme je od substance a od způsobu, kterým vyplývají $\mathrm{z}$ věčnosti, bez čehož je přece nelze správně pochopit. /viz komentár 12/

Abys to ještě lépe uviděl, vezmi tento př́iklad: totiž pojímá-li někdo trvání abstraktně a ztotožňuje ho s časem, začne ho dělit na části, nemůže nikdy pochopit, jak může např́klad uplynout [jedna] hodina. Nebot' aby uplynula [jedna] hodina, bude nutné, aby napřed uplynula její polovina, a pak polovina zbylého, a posléze polovina toho, co ještě zbylo, a kdybys tak stále do nekonečna odebíral polovinu ze zbytku, nikdy nebudeš moci dojít ke konci hodiny. Proto se mnozí, kteří nejsou zvyklí rozlišovat mezi pomyslnými a reálnými jsoucny, odvažují seriózně tvrdit, že trvání se skládá z okamžiků, a tak eo, quòd Affectiones Substantice ab ipsâ Substantiâ separamus, \& ad classes, ut eas quoad fieri potest, facilè imaginemur, redigimus, oritur Numerus, quo ipsas determinamus. Ex quibus clarè videre est, Mensuram, Tempus, \& Numerum nihil esse prceter cogitandi, seu potiùs imaginandi Modos. Quare non mirum est, quòd omnes, qui similibus Notionibus, \& quidem proeterea malè intellectis, progressum Naturce intelligere conati sunt, adeò mirificè se intricârint, ut tandem se extricare nequiverint, nisi omnia perrumpendo, \& absurda etiam absurdissima admittendo. ${ }^{20}$ Nam cùm multa sint, quce nequaquam imaginatione; sed solo intellectus assequi possumus, qualia sunt Substantia, Aternitas, \& alia. Si quis talia ejusmodi Notionibus, quce duntaxat auxilia Imaginationis sunt, explicare conatus: nihilo plus agit, quàm si det operam, ut suâ imaginatione insaniat. Neque etiam ipsi Substantice Modi, si cum ejusmodi Entibus rationis, seu imaginationis auxiliis confundantur, unquam rectè intelligi potuerunt. Nam cùm id facimus, eos à Substantiâ, \& modo, quo $a b$ aternitate fluunt, separamus; sine quibus tamen rectè intelligi nequeunt.

Quod ut adhuc clariùs videas, cape hoc exemplum: nempe, ubi quis Durationem abstractè conceperit, eamque cum Tempore confundendo in partes dividere inceperit, nunquam poterit intelligere, quâ ratione hora ex. grat. transire possit. Nam ut hora transeat, necesse erit, ejus dimidium prius transire, \& postea dimidium reliqui, \& deinde dimidium, quod hujus reliqui superest; \& si sic porrò infinite dimidium à reliquo subtrahas, nunquam ad finem horce pervenire poteris. Quare multi, qui Entia rationis à realibus distinguere assueti non sunt, Durationem ex momentis componi, ausi sunt asseverare, \& sic in Scyllam inciderunt cupientes vitare Charybdim. ${ }^{21}$ Idem enim est Durationem ex momentis componere, quàm Numerum ex solâ nullitatum additione. 
podléhají Scylle chtějíce uniknout Charybdě. ${ }^{22}$ Skládat trvání z okamžiků je totiž stejné jako [tvořit] číslo pouhým přičítáním nul. Ze způsobu výkladu je dále dostatečně zřejmé, že ani číslo, ani míra, ani čas, nakolik nejsou než pomůckami představivosti, nemohou být nekonečné, nebot' jinak by číslo nebylo číslem, míra mírou, čas časem. $Z$ toho je jasně vidět, proč mnozí, kteří tuto trojici [zmateně] pomíchali se samotnými věcmi, protože pravou povahu věcí neznali, popřeli skutečné nekonečno. ${ }^{23}$ Avšak v jaké míře uvažovali prachšpatně, to necht' posoudí matematici, kterým argumenty takového druhu nemohly způsobit žádné obtíže ve věcech, které vnímali jasně a rozlišeně. Nebot' mimo to, že objevili mnohé [věci], které nemohou být vysvětleny žádným číslem (což viditelně odhalilo neschopnost čísel všechno vymezit [a určit]), mají také mnohé [věci], které nelze [přiměřeně] vyjádřit žádným číslem, nýbrž každé číslo, které může být dáno, převyšují. A přece $\mathrm{z}$ toho nevyvozují, že takové [věci] převyšují každé číslo kvůli množství částí, nýbrž [vyvozují to] proto, že povaha věci nemůže číslo snést [strpět] bez zjevného rozporu /viz komentár $13 /$. Tak např́klad převyšují každé číslo všechny různosti (nestejnosti) vzdálenosti umístěné mezi dvěma kruhy $A, B$ a $C, D^{24}$ a všechny proměny, které musí prodělat matérie pohybující se $\mathrm{v}$ tom [prostoru]. A to se nevyvozuje $\mathrm{z}$ nesmírné velikosti meziprostoru. Nebot' at' vezmeme jakkoli malou jeho část, ${ }^{25}$ přece $\mathrm{i}$ nerovnosti této malé části budou převyšovat každé číslo. Stejně tak se [takový závěr] nevyvozuje, jak se děje $v$ jiných [př́padech], kvůli tomu, že nemáme jeho [tj. onoho meziprostoru] maximum a minimum. Obojí totiž v tomto našem př́ikladu máme, tj. maximum $\mathrm{A}, \mathrm{B}$ a minimum $C, D$. Vyvozuje se to pouze a jen $\mathrm{z}$ toho, že povaha meziprostoru mezi dvěma kruhy majícími rozdílné středy nic takového nemůže strpět. A proto kdyby někdo chtěl ony všechny nerovnosti vymezit nějakým
Porrò cùm ex modò dictis satis pateat, nec Numerum, nec Mensuram, nec Tempus, quandoquidem non nisi auxilia

imaginationis sunt, posse esse infinitos: Nam alias Numerus non esset numerus, nec Mensura mensura, nec Tempus tempus. Hinc clarè videre est, cur multi, qui hoec tria cum rebus ipsis confundenbant, propterea quòd veram rerum naturam ignorabant, Infinitum actu negârunt. Sed quàm miserè rationati sint, judicent Mathematici, quibus hujus farince Argumenta nullam moram injicere potuerunt in rebus, ab ipsis clarè, distincteque perceptis. Nam proterquam quòd multa invenerunt, quce nullo Numero explicari possunt; quòd satis numerorum defectum ad omnia determinandum patefacit: multa etiam habet, quo nullo numero adcequari possunt; sed omnem, qui dari potest, numerum superant. Nec tamen concludunt, talia omnem numerum superare ex partium multitudine: sed ex eo, quod rei natura non sine manifestâ contradictione numerum pati potest, ut ex. grat. omnes incequalitates spatii duobus circulis $A B, \& C D$, interpositi ${ }^{26}$, omneque variationes, quas materia, in eo mota, pati debeat, omnem numerum superant. Idque non concluditur, ex nimiâ spatii interpositi magnitudine: Nam quantumvis parvam ejus portionem capiamus, hujus tamen parvee portionis incequalitates omnem numerum superabunt. Neque etiam idcircò concluditur, ut in aliis contingit, quòd ejus maximum, \& minimum non habeamus: utrumque enim in hoc nostro exemplo habemus, maximum nempe $A B$, minimum verò $C D$ : Sed ex eo tantum concluditur, quòd natura spatii inter duos circulus, diversa centra habentes, interpositi nihil tale pati possit. Ideoque si quis omnes illas incequalitates certo aliquo numero determinare velit, simul efficere debebit, ut circulus non sit circulus.

Sic etiam, ut ad nostrum propositum revertar, si quis omnes materice motûs, qui hucusque fuerunt, determinare volet, eos 
určitým číslem, musel by zároveň způsobit, aby kruh nebyl kruhem.

Tak také, abych se vrátil k tomu, co jsme si předsevzali, kdyby někdo chtěl všechny pohyby matérie, které se až dosud děly, vymezit tím, že by je a jejich trvání vztáhl $\mathrm{k}$ určitému číslu a času, ten jistě nebude usilovat o nic jiného než tělesnou substanci, jež můžeme pojímat jen jako existující, zbavit jejích stavů a způsobit, aby neměla tu přirozenost, kterou má. To bych zde mohl jasně dokázat, jakož i mnohé jiné [věci], které jsem v tomto dopise zmínil, kdybych to nepovažoval za zbytečné.

Ze všeho již uvedeného je jasně vidět, že něco je nekonečné svou přirozeností a žádným způsobem nemůže být pojato jako konečné; něco je pak [nekonečné] silou příčiny, které inheruje, avšak může být, pokud je pojato abstraktně, rozděleno do částí a nahlíženo jako konečné; a konečně pak něco je nazváno nekonečným nebo, chceš-li neomezeným, protože to nelze [přiměřeně] vyjádřit žádným číslem, avšak přesto to může být pojímáno jako větší a menší, protože $\mathrm{z}$ toho, že to nelze [přiměřeně] vyjádřit číslem, neplyne, že to musí být nutně rovno [jinému číslem nevyjádřitelnému], jak je dostatečně zřejmé z uvedeného př́íkladu a mnohých jiných.

Alespoň krátce jsem objasnil příčiny omylů a zmateností, které vzešly z otázky [po povaze] nekonečna. A pokud se nemýlím, objasnil jsem je všechny tak, že jsem přesvědčen, že nezbyla žádná otázka týkající se nekonečna, kterou jsem zde nezmínil nebo která by nebyla $\mathrm{z}$ uvedeného co nejsnadněji řešitelná. Proto se nedomnívám, že má cenu tě déle zdržovat $\mathrm{v}$ těchto záležitostech.

Mimochodem bych však zde chtěl poznamenat /viz komentár 14 , že současní peripatetici, ${ }^{27}$ jak se mi zdá, špatně porozuměli důkazu starých [peripatetiků], kterým usilovali o dokázání existence Boha. Nebot' ten, jak ho nacházím vyslovený u jakéhosi Žida zvaného rabi Chasdaj ${ }^{28}$, zní ${ }^{29}$ : Je-li dán nekonečný sled scilicet, eorumque Durationem ad certum numerum, \& tempus redigendo; is certe nihil aliud conabitur, quàm Substantiam corpoream, quam non nisi existentem concipere possumus, suis Affectionibus privare, \&, ut naturam, quam habet, non habeat, efficere. Quce clarè demonstrare hîc possem, ut \& alia multa, quoe in hâc Epistulâ attigi, nisi id superfluum judicarem.

Ex omnibus jam dictis clarè videre est, quoedam suâ naturâ esse infinita, nec ullo modo finita concipi posse; quce verò vi causce, cui inhoerent, quae tamen, ubi abstractè concipiuntur, in partes possunt dividi, \& ut finita spectari; quoedam denique infinita, vel si mavis, indefinita dici, propterea quòd nullo numero adcequari queant, quce tamen majora, \& minora possunt concipi; quia non sequatur, illa necessariò debere esse cequalia, quce numero adcequari nequeunt, ut ex exemplo, \& aliis multis satis est manifestum.

Denique causas errorum, \& confusionum, quce circa Qucestionem de Infinito ortce sunt, breviter ob oculos posui, easque, ni fallor, ità explicui omnes, ut non putem ullam superesse circa Infinitum Qucestionem, quam hic non attigi, aut quae ex dictis facillimè solvi ${ }^{30}$ non queat. Quare in his te detinere diutius, operce pretium esse non judico.

Verùm hîc obiter adhuc notari velim, quòd Peripatetici recentiores $^{31}$, ut quidem puto, malè intellexerunt demonstrationem Veterum, quâ ostendere nitebantur Dei existentiam. Nam, ut ipsa apud Judceum quendam Rab Chasdaj vocatum, reperio, sic sonat. ${ }^{32}$ Si datur progressus causarum in infinitum, erunt omnia, quoe sunt, etiam causata: Atqui ${ }^{33}$ nulli, quod causatum est, competit, vi suce naturce necessariò existere: Ergo nihil est in naturâ ad cujus essentiam pertinet necessariò existere. Sed hoc est absurdum: ergo \& illud. Quare vis argumenti non in eo sita est, quòd impossibile sit, dari actu Infinitum, ${ }^{34}$ aut progressus causarum in infinitum: Sed 
prríčin, pak bude mít vše, co jest, také příčinu. Avšak přece ničemu, co má příčinu, nepř́sluší existovat nutně silou své přirozenosti. Tedy není $\mathrm{v}$ př́rodě nic, k esenci čeho náleží nutně existovat. Ale to je nesmyslné, tedy je nesmyslné i to [první]. Pročež síla argumentu nespočívá $\mathrm{v}$ tom, že je nemožné, aby bylo dáno aktuálně nekonečné nebo nekonečný sled příčin, nýbrž toliko $\mathrm{v}$ tom, že se zde předpokládá, že věci, které neexistují nutně ze své přirozenosti, nejsou určeny $\mathrm{k}$ existování [ničím jiným než] ${ }^{35}$ věcí existující nutně ze své přirozenosti.

Protože mne čas nutní spěchat, přejdu k Tvému druhému dopisu. Avšak na to, co je v něm obsaženo, budu moci pohodlněji odpovědět, až uznáš za vhodné mne navštívit. Prosím tedy, pokud můžeš, přijed' co nejdříve, nebot' čas stěhování se rychle blíží. Tolik prozatím. Bud' zdáv a pamatuj na mne, který jsem atd.

Rijnsburg 20. dubna 1663 tantum in eo, quòd supponatur, ${ }^{36}$ res, quoe suâ naturâ non necessariò existunt, non determinari ad existendum à re suâ naturâ necessariò existenti ${ }^{37}$ \{,en die oorzaak, /Causa/, geen veroorzaakte, /Causata/, is\}. Transirem jam, quia tempus me festinare cogit, ad secundum tuam Epistolam: sed ad ea, quoe isthâc continentur, commodiùs, cum dignatus fueris me invisere, respondere potero. Quceso itaque, si fieri

potest, ut quàmprimùm venias; nam tempus migrandi festinanter accedit. Tantum est. Vale, meique memor vive, qui sum, $\& c{ }^{38}$

\{Te Rijnsburgu, 20. April 1663.\} 


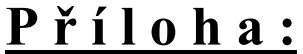

Zobrazení př́kladu se dvěma nesoustřednými kruhy, který v textu dopisu použil B. Spinoza.

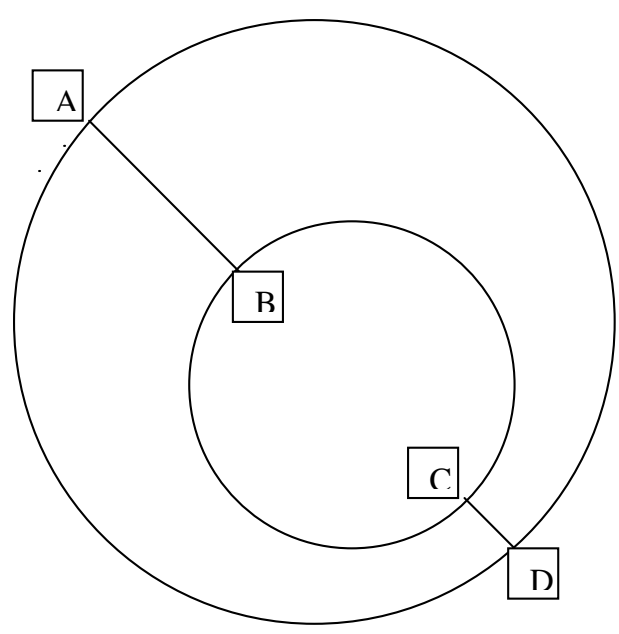




\section{Komentáře:}

1. Aaron V. Garrett k tomuto místu poznamenává, že holandský filosof oznamuje svému prŕiteli L. Meyerovi závěry ze svých úvah o nekonečnu způsobem, který má zvýraznit jedinečnost jeho objevu a zároveň je doprovázen jakousi ,autorskou pýchou“. 39

Neshledávám žádný důvod k tomu, abychom se domnívali, že zde jde o oznámení člověka, jenž je (dokonce snad značně) pyšný na své odhalení něčeho jedinečného. B. Spinoza zcela prostě reaguje na přítelovy žádosti $\mathrm{z}$ předchozích dopisů $\mathrm{s}$ tím, že zdůrazňuje původní směr svých úvah. Ty totiž zřejmě směřovaly zejména $\mathrm{k}$ tomu, co si filosof již dříve stanovil jako základní metodické předpoklady svých filosofických zkoumání a co zachytil ve svém raném ${ }^{40}$ nedokončeném traktátku Pojednání o nápravě rozumu. Zde mimo jiné jasně stanovuje, ,jaká je první cesta, jež musí mysl nastoupit, aby dobře začala - totiž ta, na které by mohla postoupit ke zkoumání určitých zákonů dle měřítka kterékoli dané pravdivé ideje. Má-li se to dít správně, musí metoda umožnit následující: za prvé odlišit pravdivou ideu ode všech ostatních poznatků a zdržet od nich mysl..."41 To znamená, že při svých úvahách o nekonečnu zcela přirozeně postupoval tak, že se nejprve pokusil odlišit a rozlišit způsoby, kterými byl problém nekonečna zpracováván, a na základě toho také určit přiměřenost těch či oněch idejí nekonečna, se kterými myslitelé pracovali v minulosti i v jeho současnosti. Nejedná se tedy o nějaký zásadní objev, ale o výsledek uplatnění základních metodických principů, tj. o to, co musí metoda umožnit: „stanovit pořádek z důvodu nezdržování se neužitečnostmi.““42

$S$ ohledem na to $B$. Spinoza informuje svého prrítele o tom, že dobrat se některých důležitých závěrů při zkoumání povahy nekonečna znamená pracovat s velmi přesnými „distinkcemi“ neboli s přesným rozlišováním mezi různými rovinami, na kterých problém nekonečna uvažujeme.

Ostatně filosof sám na to poukazuje tím, že v dalším pokračování svého listu píše o tom, že důsledným prováděním takových rozlišení a velkou pozorností, kterou je třeba jim věnovat, je možné se uvarovat ohromných obtíží (turbâ difficultatum), které jinak na kohokoli přemýšlejícího o nekonečnu číhají. Vskutku v tom tedy nespatřuji žádné „,anoncování“ jedinečného objevu, ale spíše velmi stř́zlivé uplatnění jistých metodických postupů, které Spinoza považoval za rozhodující klíč k porozumění všem složitějším otázkám, nejen otázce po povaze nekonečna.

Kromě toho jsem přesvědčen, že by Spinoza nemohl považovat své závěry za „své“ objevy. Činností mysli, je-li přesná a správná, tedy zejména přesně rozlišující, se totiž „objevuje“ věc sama. Je to její „objevování se“, nikoli náš, resp. Spinozův „objev“. Přesně rozlišující činnost mysli je tím, skrze co se věc „objevuje“. My pravdu neobjevujeme, pravda (pravá filosofie) nalézá nás.

2. Spinoza stanovuje první (a skutečně fundamentální) rozlišení takto: Je bezpodmínečně nutné rozlišovat mezi dvěma významy slova „nekonečné“, resp. mezi dvojím, co může být tímto slovem označeno:

a) Nekonečné (jakožto to, co nemá žádné hranice) = to, čeho nekonečnost je v samotné jeho přirozenosti (esenci) neboli z významu definice čeho nekonečnost prímo a bezprostředně vyplývá, resp. je zřejmá.

b) Nekonečné (jakožto to, co nemá žádné hranice) = to, čeho nekonečnost je garantována mocí (silou) jeho př́íčiny. 
Jak máme rozumět př́ípadu (a) ?

To je vskutku ten nejvlastnější význam slova „nekonečné“ (infinitum). To, co je takto označeno, je zcela a naprosto reálně nekonečné ve všech možných ohledech. Je to absolutně nekonečné, protože to nemá žádné vnější ani vnitřní hranice, konce či omezení. Něčemu takovému je nekonečnost přirozeně (esenciálně) vlastní a je $\mathrm{v}$ důsledku toho nekonečné sebou samým. Kromě sama sebe také není ničím způsobitelné, zapříčinitelné či jinak určitelné a vymezitelné. Ve své absolutní nekonečnosti se všemu vymyká a není na ničem závislé, tj. náleží mu absolutní autonomie. Jeho neurčitosti přitom musíme rozumět nikoli jako prázdnotě či absenci všech určení, ale naopak jako plnosti, bohatosti a nevyčerpatelnosti všech určení. Ze všech uvedených charakteristik zároveň vyplývá, že to jsou pouze přibližné charakteristiky, nebot' něco takového zůstává ve své absolutní nekonečné plnosti pozitivně zcela nemyslitelné a $\mathrm{v}$ tomto ohledu nepoznatelné. Na druhé straně alespoň v tomto více či méně negativním (je to ne-konečné, neurčité, ne-omezitelné, ne-závislé atd.) způsobu to můžeme obmýšlet.

Jak je zřejmé z následného pokračování Spinozova dopisu, měl fillosof v té době již jasno v tom, že pro něco takého existuje i tradiční filosofický termín - substance. Zároveň však je třeba upozornit na to, že v té době přemýšlel rovněž o způsobu podání svého filosofického rozvrhu a sestavoval si první obrysy svého budoucího velkého pojednání Etika. V jeho první části (O Bohu) se přiklonil k tomu, že pro to, co bylo výše charakterizováno, zvolil nakonec raději filosoficko-teologický termín Bůh (Deus). Svědčí o tom struktura definičních výměrů, které filosof podal hned na úvod oné první knihy. V sestavě sedmi definic se totiž objevila definice substance i definice Boha, přičemž výše uvedeným charakteristikám odpovídá přesně definiční výměr Boha:

„Bohem rozumím absolutně nekonečné jsoucno, tj. substanci sestávající z nekonečného počtu atributů, z nichž každý vyjadřuje věčnou a nekonečnou esenci.“

Vzápětí k této definici podává vysvětlení: „,̌íkám „absolutně nekonečné“, nikoli „,nekonečné svého druhu“, protože cokoli je nekonečné pouze ve svém druhu, tomu můžeme upř́it nekonečný počet atributů. Je-li však něco absolutně nekonečné, pak k jeho esenci náleží vše, co vyjadřuje esenci a v sobě nezahrnuje žádnou negaci. “43

Oproti tomu výměr substance zní: , Substancí rozumím to, co je samo v sobě a co je chápáno ze sebe sama, tj. to, k utvoření jehož pojmu není zapotřebí pojmu nějaké další věci.“44

Podle mého soudu to svědčí o tom, že v době, kdy psal dopis L. Meyerovi, Spinozovi ještě tolik do popředí nevystoupila potřeba přesného fixování významu a postavení pojmů substance a Boha. Toto postavení (význam) totiž začalo být výrazně důležité teprve tehdy, když Spinoza podrobně vypracovával svi̊j ontologicko-etický rozvrh. Pak už bylo zřejmé, že termín „Bůh“ bude vyhrazen právě pro označení toho, co je ,absolutně nekonečné“ (přesně ve smyslu výše vedených charakteristik) a co může být pojato rovněž jako substance ve smyslu výše uvedeného definičního výměru.

Máme-li tedy odpovědět na položenou otázku, pak by odpověd’ zněla: Př́ípadu (a) je nutno rozumět jakožto ,,absolutně nekonečnému jsoucnu“ ( a mohli bychom dodat na základě znění jednoho z filosofových dopisů H. Oldenburgovi „a nejvýše dokonalému jsoucnu“445), tj. Bohu. Kromě toho bych rád upozornil na to, že uvedené definiční výměry z Etiky také umožňují uvidět onen rozdíl mezi př́padem (a) a (b) z trochu jiného úhlu pohledu. Je to patrné ve vztahu $\mathrm{k}$ vysvětlení, které filosof podal ke svému vymezení Boha. V něm se totiž objevuje důležité terminologické rozlišení mezi výrazy „absolutně nekonečné“ a „nekonečné svého druhu“. Uvědomme si, že jádrem tohoto rozlišení je př́itomnost či nepř́itomnost ,záporu“ (negace). $\mathrm{V}$ absolutně nekonečném jsoucnu není absolutně žádná negace, ve jsoucnu, jež je nekonečné ve svém druhu, nějaké popření či negace vyloučena není. Budiž to pro nás východiskem k odpovědi na otázku: 
Jak máme rozumět př́ípadu (b) ?

Abychom dobře porozuměli tomu, o jakou distinkci se Spinozovi jednalo, bude vhodné vzít v úvahu 15. tvrzení z první knihy Etiky, které zní: „Cokoli je, je v Bohu a bez Boha nemůže ani být, ani být chápáno.“46 Hovoří se zde o „čemkoli, co jest“, to znamená, že pod toto označení je nutno zahrnout Boha (k němuž se jakékoli ,jest“ vztahuje) a vše ostatní, čemu náleží výsadní pozitivita ,jest". Je-li z hlediska výše uvedených charakteristik Bůh nekonečný ve smyslu př́padu (a) a je-li tomu tak, že pouze a jedině on sám, zcela exkluzivně a jedinečně, naplňuje tyto charakteristiky, pak je samo sebou zřejmé, že př́pad (b) se může vztahovat pouze k tomu, co spadá pod označení „ostatní“, tj. k tomu, co ,jest“", avšak není to Bohem samotným, ( $Z$ hlediska dikce celého Spinozova dopisu je patrné, že bychom správně měli říci, že to není „samotným Bohem či substancí“. S ohledem na strukturu definicí z první knihy Etiky lze uvažovat pouze Boha.) nýbrž je to $\mathrm{v}$ Bohu a z Boha chápáno.

Pokud máme na zřeteli celkový spinozovský ontologický rozvrh, pak přichází v úvahu dvojí totiž atributy a mody. Nicméně v dopise samotném uvažuje filosof především mody. Důvod je nasnadě: podle 4. definice první knihy Etiky Spinoza atributem rozumí to, „co rozum postihuje ze substance jako něco takového, v čem záleží její esence. “47 Atribut je proto cosi, co v sobě nese markantní stopy „subjektivního“ (je tím, co rozum postihuje), a v tomto smyslu se k němu nelze vztahovat tak, jako $\mathrm{k}$ něčemu objektivně nekonečnému (či konečnému). Ostatně to odpovídá základnímu charakteru Spinozových ontologických úvah zachycených $\mathrm{v}$ jeho raných spisech, kde je často zdůrazněno, že jsoucnem (tím, co jest) je pouze dvojí - substance a modus. „Z vymezení nebo, chcete-li z popisu, který byl již podán, lze snadno nahlédnout, že jsoucno je třeba dělit na jsoucno, které existuje nutně ze své přirozenosti neboli jehož esence zahrnuje existenci, a na jsoucno, jehož esence zahrnuje existenci pouze jako možnou. V konečném důsledku se jsoucno takto dělí na substanci a modus. “48

U modů se tedy můžeme setkat $\mathrm{s}$ př́ípadem (b). Podle 5. definice z první knihy Etiky máme modem rozumět stav substance neboli „to, co je $v$ něčem jiném a je $z$ toho jiného také chápáno. “ ${ }^{49}$ Nekonečno, které lze k modům vztáhnout, je tedy nekonečnem v jiném nekonečnu, je jím zakládáno a garantováno a skrze něj je vůbec pochopitelné jakožto nekonečné, jež př́sluší něčemu $\mathrm{v}$ zásadě a principiálně konečnému a mohoucímu existovat $\mathrm{i}$ neexistovat. Je to paradoxní, a proto to musí být pečlivě vysvětleno a objasněno. V jakém smyslu může být něco ze své přirozenosti nekonečného tím, co v konečném způsobuje (zapříčiňuje) nějaké nekonečné momenty ? Z esenciálně nekonečného jsou absolutně vyloučeny všechny meze a hranice, stavy substance jsou podle svého výměru omezeny a určeny, a proto $\mathrm{z}$ nich nemůže být jakákoli hranice vyloučena. Není tomu tak, že nekonečnost modů (stavů substance) je spíše dána neschopností našeho rozumu či poznání určit hranice, které jinak reálně existují, a proto má taková nekonečnost více méně subjektivní charakter. M. Gueroult ${ }^{50}$ ve svém výkladu poukazuje na to, že pak by tento př́pad připomínal descartovské „neomezeno“ (indefinitum). ${ }^{51}$ Vzápětí však sám poukazuje na rozdíly př́stupu obou filosofů. Karteziánské neomezeno je eminentně subjektivní a má svůj původ $\mathrm{v}$ naší neschopnosti rozhodnout, zda je věc konečná nebo objektivně neomezená. Spinozovské nekonečno případu (b) je objektivní neomezeno založené v nekonečnosti jeho základu (příčiny) a konečnosti jeho esence. ${ }^{52}$

Každý modus (jednotlivá věc) v sobě obsahuje cosi z absolutně nekonečného základu - jeho činná esence (essentia actuosa), tj. „,snaha, s níž se libovolná věc snaží setrvávat ve svém bytí'“53, je totiž jakožto podíl oné jednotlivé věci na absolutně činné moci absolutního základu neomezená, nemůže být ničím omezena, tedy nemá žádné hranice. Spinoza doslova tvrdí: „Snaha, s níž se libovolná věc snaží setrvat ve svém bytí, nezahrnuje žádný omezený čas, nýbrž zahrnuje čas neomezený. “54 V tomto smyslu je ona „snaha“ jednotlivé věci (modu) vyjádřením nekonečného (nekonečné moci být a jednat) v omezeném, určitém, tj. konečném. Zdroj nekonečného je ovšem bytný základ sám, absolutně nekonečný Bůh, a nikoli jednotlivá věc. Proto je nutné tak pečlivě rozlišovat mezi nekonečnem prrípadu (a) a případu (b). 
Je zde ovšem ještě jeden důležitý moment, který nelze přehlédnout. Kromě toho, že se nekonečné př́ípadu (b) vztahuje k modům jakožto jednotlivým věcem, vztahuje se také k dalším modálním jsoucnům, které však nemají povahu jednotlivé věci, nýbrž jsou to charakteristiky celého universa. Jedná se o „nekonečné mody“ (modi infiniti) - totiž „,celkové utváření (tvářnost) př́rody“ (,...celá př́roda je jedním individuem, jehož části, tj. všechna tělesa, se nekonečnými zpưsoby mění, aniž se celé individuum jakkoli mění. “55), „nekonečná rozlehlost“", „nekonečné myšlení (rozum)“, „nekonečný pohyb“ aj. Jejich nekonečnost je samozřjmě rovněž objektivní, nevyjadřuje se však zprostředkovaně v omezeném jednotlivém, nýbrž jaksi př́mo tím, že jsou charakteristikami celku, který je absolutně nekonečný. Zdrojem jejich nekonečnosti ovšem nejsou ony samy, nýbrž opět to, k čemu se váží - tedy absolutní základ sám. (Jejich přirozeností je „být charakteristikou celku“.)

Takto je z hlediska prvního typu distinkce, na který Spinoza ve svém dopisu L. Meyerovi upozorňuje, nutno rozlišovat mezi dvěma případy nekonečného.

3. Další rozlišení, se kterým holandský filosof přichází, je rozlišení spočívající v určitém posunutí pohledu. Jedná se o to, že termín nekonečné je možno použít bez komplikací tam, kde má být označeno něco, co vskutku „,nemá konce“, „nemá žádné hranice, omezení apod.“, je tedy v prostém smyslu ne-konečné, bez-konce. Je ho ovšem možné použít i tam, kde na první pohled hranice jsou, kde existují nějaké limity (minimum, maximum) a kde tedy má být označeno něco, co je ne-konečné ve specifickém smyslu, totiž ne-konečné uvnitř jistých konců či mezí. Jinak vyjádřeno: je potřebné rozlišovat mezi tím, co je nesporně bez konců (nekonečné), protože jeho přirozenosti jakékoli konce, hranice či limity odporují (Bůh, substance, nekonečné mody), a tím, co je ne-konečné uvnitř určitých hranic či limit.

První případ skutečně nekonečného, tedy nemajícího konců, se vyznačuje mimo to, co jsme uvedli v komentáři 2, také tím, že toto nekonečné vylučuje jakoukoli dělitelnost do konečných částí. 13. tvrzení první knihy Etiky Spinoza formuluje jasně: „Absolutně nekonečná substance je nedělitelná. “56 (V poznámce k 15. tvrzení téže knihy pak upozorňuje na to, že předpoklad dělitelnosti nekonečné substance, tj. předpoklad že se skládá z částí, vede nakonec $\mathrm{k}$ absurdnímu závěru, že substance musí být konečná. Pokud někdo takový závěr z nesmyslného předpokladu vyvodí, pak si „opravdu počíná jako člověk, jenž vymyslel kružnici s vlastnostmi čtverce a vyvodil z toho závěr, že kružnice nemá střed, od něhož mají všechny body stejnou vzdálenost. ${ }^{\text {"577) }}$ Nekonečno je v tomto př́padě nekonečnem jedinečným, celistvým, jednolitým a nepřerušitelným.

Naproti tomu druhý př́pad nekonečného uvnitř jistých hranic nutně musí dělitelnost připustit, resp. nemůže ji vyloučit, nebot' co má maximum a minimum, to lze jistě rozdělit. Je to tedy př́ípad nekonečna uzavřeného $\mathrm{v}$ jistých hranicích, a proto omezeného, dělitelného $\mathrm{a}$ přerušitelného. Je proto nezbytně nutné vysvětlit, $\mathrm{v}$ jakém smyslu může být uvažováno o dělitelnosti nekonečného do částí. První „,conditio sine qua non“, kterou sám Spinoza vzápětí uvádí, je to, že části tohoto nekonečného nelze spočítat, nelze je vyjádřit nějakým počtem neboli číslem. ${ }^{58}$ Co to znamená? V zásadě to lze vyjádřit jednoduše: počet částí tohoto nekonečného je nekonečný, a proto se každému číslu (počtu) vymyká. Důvod tohoto vymykání je nasnadě. $\mathrm{V}$ př́padě vyjádřitelnosti počtu částí číslem by byla nezvratně narušena sama povaha nekonečného, která je číslem nevyjádřitelná. Snaha o takové vyjádření vede nutně k destrukci nekonečného, jehož pojem se okamžitě rozpadá a je neudržitelný. Samozřejmě, že je nutno ponechat stranou situaci, kdy termín „nekonečné“ je pouze synonymním vyjádřením nespočitatelného množství, tj. takového množství, jež je tak veliké, že je nemožné, abychom ho spočetli, ba dokonce si ho představili jako spočitatelné. Tehdy se totiž nejedná o skutečně nekonečné. Je to cosi (kvazi)nekonečného ze subjektivních důvodů (neschopnosti intelektu a deficitu představivosti). 
Další podmínkou úvah o takovém nekonečnu je pak uvědomění si modální povahy oné dělitelnosti tohoto omezeně nekonečného, tj. způsobu, kterým se naše mysl k něčemu takovému vztahuje, způsobu jakým dělitelné nekonečno chápe. To bezprostředně souvisí s třetí distinkcí, kterou Spinoza uvádí. O ní pojednáme ve zvláštním komentáři.

(Připojme ještě jednu objasňující poznámku: Ze znění Spinozova dopisu i z toho, co napsal ve svých pozdějších pojednáních, snad dostatečně jasně plyne, že termín „,nekonečné“ může být vztažen ve vlastním a plném smyslu jen a pouze k Bohu. Mimo tuto relaci je tento termín uplatňován vždy jen nevlastním způsobem. $Z$ toho však nelze soudit, že holandský myslitel se zasazoval o jakousi restrikci podobného uplatňování. Naopak účelem jeho odpovědi na otázky L. Meyera bylo právě pečlivě poukázat na to, že uplatnění termínu „nekonečné“ má své opodstatnění i v onom nevlastní způsobu. Je pouze nezbytně třeba být si vědom určitých specifických podmínek takového uplatnění, o nichž se Spinoza vždy zmiňuje a patřičně je zdůrazňuje.)

4. Již $\mathrm{v}$ předchozím komentáři jsme naznačili, že $\mathrm{v}$ případě nekonečna, které je nekonečnem dělitelným a uzavřeným $v$ jistým hranicích, je bezpodmínečně nutné uvědomit si, jakými způsoby ho (i jeho dělitelnost) naše mysl chápe či se ho zmocňuje. Nejdůležitějším odlišením přitom je distinkce mezi tím, co si představujeme či můžeme představovat a posléze chápat, resp. nechápat, a tím, co si představit nelze a je to pouze pochopitelné rozumem. Této distinkce si byl Spinoza v době, kdy psal svůj dopis L. Meyerovi, již dávno vědom a vždy ji měl na zřeteli.

V jeho nejranější (nedokončené) práci Pojednání o nápravě rozumu nalézáme takto jasné formulace: „Takto jsme tedy rozlišili pravdivé ideje a ostatní poznatky a ukázali jsme, že ideje smyšlené, klamné a ostatní mají svůj původ v představivosti, tj. v nějakých (mám-li se tak vyjádřit) nahodilých a nesouvislých vjemech, které nevznikají z moci mysli samé, ale z vnějších prričin tak jak tělo vnímá, at' už v bdělém stavu nebo ve snění, různé pohyby. Nebo je-li libo, chápej zde představivost, jakkoli chceš, jen když bude něčím rozdílným od rozumu a něčím, co zachová duši její pasivní ráz. Potom co jsme poznali, že představivost je něčím nejistým a duše se v ní stává pasivní, a zároveň potom co jsme také poznali, jak se od ní můžeme pomoci rozumu osvobozovat, je vcelku jedno, co pod představivostí rozumíšs “" ${ }^{\text {"R9 }}$ „Rovněž se nedivíme, proč chápeme něco, co žádným způsobem nespadá do představivosti, a že naopak $\mathrm{v}$ představivosti jsou jiné věci, které rozumu zvláště odporují, a také jiné, které s rozumem souhlasí. Vždyt' jsme konec konců poznali ony úkony, kterými jsou představy vytvářeny, i to, že se dějí podle jiných, od zákonů rozumu výrazně odlišných zákonů a že se duše vzhledem $\mathrm{k}$ představivosti chová vždy pasivně. $\mathrm{V}$ tom je také založeno to, že do velikých omylů mohou snadno upadnout ti, kteří přesně nerozlišují mezi představováním a chápáním. “60

I v dalším raném spinozovském textu, Metafyzických myšlenkách, se setkáme s př́sným odlišováním představ a idejí, resp. představivosti a rozumu. „Konečně pak jsme zvyklí si vše, čemu rozumíme, také zobrazovat v naší fantazii nějakými představami. $Z$ toho pak pochází i to, že si dokonce představujeme nejsoucna stejně pozitivně jako jsoucna. Nebot' mysl nahlížena sama v sobě jako věc myslící nemá větší moc k přitakání než k popření. S protože představování není nic jiného než vnímání stop, které v mozku zanechal pohyb duchů vyvolaný ve smyslech vnějšími předměty, tak nemůže být takové vnímání ničím jiným než zmateným přitakáním. “61 O několik let později už se Spinoza spokojil s krátkým vyjádřením svého stanoviska. Ve druhé knize Etiky to je vyjádřeno lapidárně v důsledku k 26. tvrzení: „Pokud lidská mysl poznává vnější těleso prostřednictvím představy, nemá jeho adekvátní poznání. “62

Spinozovsky pojímané rozdíly mezi představivostí a rozumem přehledně zachytil ve své studii M. Gueroult: ${ }^{63}$ 
- rozumění poznává esence, představivost poznává pouze existenci; rozum zachycuje věci, jak jsou v sobě, představivost se zmocňuje pouze toho, jaké stavy věci vyvolávají $\mathrm{v}$ našem těle

- představivost může znát pouze mody, substance (která nepůsobí přímo na naše tělo) jí uniká (Dodejme k tomu: Substance na naše tělo př́ímo působit ani nemůže, protože $\mathrm{v}$ prŕípadě takového působení by byl narušen nutný řád, nutné uspořádání vezdejšího sledu příčin a následků, které je vezdejším vyjádřením esence substance. Narušením takového řádu by substance narušovala sama sebe, což je absurdní.)

- mody jsou poznatelné představivostí i rozumem, avšak pouze rozum je poznává jakožto mody substance, kdežto představivost je pojímá jakožto stavy našeho těla, tj. zmateně

- představivost pojímá mody jako vzájemně nezávislé jeden na druhém, jako reálně oddělené, čímž diskontinuitně rozbíjí to, co je ve vlastním smyslu spojité, nebot' všechny mody nejsou konec konců ničím jiným než způsoby vyjádření esence absolutně nekonečného základu

Bližší objasnění těchto rozdílů si lze provést v souvislosti s různými vysvětleními, které Spinoza podává v dalším pokračování svého dopisu.

5. Znovu můžeme formulovat smysl celého expozé nutných a nezbytně potřebných rozlišení. Jádro věci spočívá v tom, co už jsme jednou uvedli. Jen zdánlivě je idea (skutečného, reálného, aktuálního, vskutku jsoucího) nekonečna zdrojem neřešitelných obtíží pro lidské poznání, a proto není třeba se jí zříkat či se jí vyhýbat. Není to žádná past, do které je lidský rozum beznadějně lapen, pokouší-li se nějak obmyslit to, co ho naprosto nekonečně přesahuje. Je to zcela legitimní idea. A nejen to. Je to dokonce idea jaksi „první a základní“, bez níž pozbývá jakékoli další přemýšlení o světě a člověku v něm smyslu. (Zde mám na mysli ontologický význam či „smysl smyslu“, o němž jsem se pokusil blíže pojednat ve svých Cestách k bytí II, VŠE, Praha 2001.) Spinoza sice povětšinou nehovoří o „,ideji nekonečna“, nýbrž o ,ideji nejdokonalejšího jsoucna“, resp. o ,ideji jsoucna absolutně nekonečného a nejvýše dokonalého“ či prostě o „,ideji Boha“64, ale vzhledem k tomu, co jsem uvedl v předchozích komentáŕích, lze považovat tyto výrazy za synonymní, pokud máme na zřeteli nekonečno v plném aktuálním smyslu.

Za situace, kdy budeme mít stálý zřetel $\mathrm{k}$ této ideji nekonečna, je potřebné mít rovněž na paměti, že obmýšlíme-li svět a sebe sama v něm, přemýšlíme přirozeně o něčem, co je principiálně i fakticky odlišné od onoho plného, aktuálního nekonečna, byt' je to konec konců v něm a bez něj je to nepochopitelné, resp. pozbývá to smyslu. To znamená, že i když narazíme v tomto světě na nekonečno ( a něco takového je nejen možné, ale dokonce velice časté), nemůžeme na něj pouze „mechanicky“ přenášet způsoby, kterými jsme se pokusili (byt' je to nesmírně obtížné) přemýšlet o onom plném, reálném nekonečnu, nýbrž je nutno si uvědomit rozdílnost způsobů a obmýšlet ono „vezdejší“ nekonečno jako nekonečno modální, tj. nekonečno vztahující se ke světu modů. Pokud budeme schopni udržet své myšlení v těchto hranicích, nebude pro nás obtížné, jak nás holandský filosof upozorňuje, porozumět tomu, že to, co v žádném př́padě nelze pozitivně uplatnit ve vztahu k plném, absolutnímu nekonečnu, je možné docela dobře a bez rozporů chápat $\mathrm{v}$ prrípadě nekonečného ve světě modů.

Smysl oněch rozlišení však není pouze v jakési prevenci a uvarování se omylů a chyb, ve svém významu jsou daleko důsažnější. Ukazují totiž člověku, jakými postupy a způsoby může nalézat pevnou půdu pro své pokusy porozumět. Ve shodě s celkovou orientací Spinozova etickoontologického filosofování je uplatnění těchto distinkcí pro lidské poznání nutnou podmínkou pro adekvátní uchopení onoho nejvy̌šího principu porozumění - jsoucna absolutně nekonečného a nejvýše dokonalého, tj. Boha - a tedy jakéhokoli porozumění vůbec. $Z$ toho vyplývá, že není nutné „obávat se nekonečna“. Spíše naopak by se dalo říci, že „idea absolutního nekonečna“ poskytuje člověku tu nejvyšší možnou „útěchu“, protože je pro něj 
vždy (pokud jsou naplněny určité předpoklady, o který zejména Spinoza ve svém dopise pojednává) tím nejvyšším zdrojem smyslu. Reálné, absolutní nekonečno je nám totiž nejen nekonečně vzdáleno, ale zároveň je také nekonečně blízké.

Zde je na místě také poznamenat, že zdaleka ne vždy je tímto způsobem holandskému filosofu rozuměno. Leckdy totiž bývá spíše bezmyšlenkovitě řazen mezi představitele nastupující pověké prírodovědy (sic !) a v důsledku toho je mu pak podsouváno mnohé z toho, co bylo pro tento kulturně duchovní fenomén 17. století běžné. Týká se to bohužel i problematiky aktuálně nekonečného, kterou mnozí (i filosofující) př́rodovědci raného novověku raději ponechávali stranou, resp. ho vytěsňovali do oblasti teologických spekulací (viz např́iklad R. Descartes). Př́kladem takového výkladu myšlenek B. Spinozy budiž expozé P. Vopěnky: „Propast zející mezi člověkem a Bohem vzniklá odbouráním barokní (a vůbec jakékoliv takříkajíc nadpřirozené) nadstavby reálného světa, ostře oddělila vědu od teologie, přičemž pro neuchopitelnost aktuálního nekonečna člověkem spadl tento problém téměř do výlučné působnosti teologie. Věda na něj pohlíží jako na záležitost nerozhodnutelnou, a tedy pro činorodého západoevropana nezajímavou. O tom, že aktuální nekonečno není přístupné ani lidskému rozumu, ba ani lidské vůli, se při probírání důsledků čtyřicátého devátého tvrzení ve druhém dílu svého spisu Etika (tedy při zkoumání otázek pro vědu naléhavějších) jen jaksi

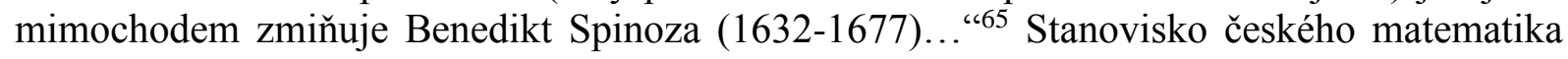
vyhlíži jednoznačně a přesvědčivě za předpokladu, že B. Spinozu budeme považovat za představitele novověké vědy (což je možné jen velice obtížně a v rozporu s mnoha faktickými skutečnostmi $\mathrm{z}$ filosofova života a $\mathrm{s}$ řadou aspektů jeho filosofického díla) a zároveň za předpokladu, že budeme soustředěni podobně jako P. Vopěnka na jednu jedinou (a ještě ne úplně přesně citovanou) tezi $\mathrm{z}$ obsáhlé Spinozovy poznámky. Oba předpoklady jsou neudržitelné v situaci, kdy z textu dopisu L. Meyerovi a z mnoha jiných pasáží Spinozových děl plyne, že pro tohoto autora byla idea aktuálně nekonečného klíčovým elementem jeho pokusu o porozumění sobě samému, Bohu a jakési věčné nutnosti věcí. Ale nejen to. Znovu opakuji, že považovat holandského myslitele za představitele novověké matematizující př́rodovědy by bylo možné pouze za předpokladu toho, že ponecháme stranou mnohé podstatné a zásadně důležité momenty jeho života i díla. A ve vztahu k poznámce ke 49. tvrzení druhé knihy Etiky je třeba si uvědomit, že Vopěnkou citované místo ${ }^{66}$ je součástí Spinozovy polemiky $\mathrm{s}$ tehdy poměrně rozššřrenou karteziánskou tezí o rozdílnosti mezi konečným rozumem a nekonečnou vůlí. Spinoza tuto tezi odmítal, přičemž při své argumentaci neměl v úmyslu popřít aktuálně nekonečné, resp. nějak marginalizovat či odsouvat jeho problematiku. To by totiž popíralo celkové zaměření jeho hlavního filosofického spisu. Pouze učinil součástí své argumentace (velmi důležité) rozlišení mezi tím, že jsme schopni svým rozumem (a tedy i vưlí) pojímat nekonečně mnoho věcí jednu po druhé a tím jim přitakávat, a tím, že totéž nejsme schopni provést pro nekonečně mnoho věcí zároveň. To ovšem nelze vykládat jako popření aktuálně nekonečného, resp. jako marginalizaci jeho př́ípadného pojímání. Podle mého soudu je to zřejmé vymezení způsobu, kterým jsou naše poznávací a pojímající mohutnosti schopny se s aktuálně (reálně) nekonečným vypořádat. Zcela to tedy zapadá do kontextu Spinozových úvah o problému nekonečna, s nimiž seznamoval svého přítele. Ostatně Vopěnkův výklad může jen s velkými obtížemi obstát v situaci, kdy si připomene, že Spinoza ve svém dopisu dává do př́mé souvislosti neznalost pravé povahy věcí a zmatené promíchání reálných věcí s pomůckami představivosti s popíráním aktuálního nekonečna. (Viz př́islušnou pasáž dopisu, v tomto překladu na str. 7.)

6. K tomu, co Spinoza uvádí ve věci substance, není třeba př́liš mnoho dodávat, nebot' to je dostatečně známé. Navíc kdybychom si chtěli prověřit a ověřit důkazní postupy, kterými filosof zakládá tyto charakteristiky pojmu substance, stačí si pročíst a promyslet zejména první až patnácté tvrzení první knihy Etiky. ${ }^{67}$ 
Z určitého stanoviska nahlíženo se však jeví nesmírně důležitým to, co říká o modech. Mody neboli stavy substance jsou totiž zvláštním způsobem dvojaké, resp. jejich dvojakost odpovídá dvojímu možnému př́stupu k nim, který může lidské poznání realizovat. Chápeme-li je jako mody substance neboli našemu poznání dostupné způsoby, kterými se vyjadřuje přirozenost substance a $\mathrm{v}$ nichž a spolu $\mathrm{s}$ nimi zakládá a vytváří celkové uspořádání vezdejšího světa (přírody), pak jsou to průkazy samotné substance (jsou to její mody) a nelze tedy pomíjet či nezohlednit jejich konečné a omezené vyjádření nekonečnosti, tj. bytostnou vztažnost $\mathrm{k}$ reálnému nekonečnu. Jestliže však nahlížíme mody v jejich konečnosti a chápeme je jako navzájem oddělené singularity, pak nutně vystoupí do popředí jejich esence ve své vymezenosti, což znamená, že v nich není nic reálně nekonečného.

A právě v tomto okamžiku je třeba mít plně na zřeteli, že tato dvojakost je právě důsledkem onoho dvojího způsobu chápání, z nichž jedno je vztaženo k tomu, co je skutečné (reálné) a plnohodnotné, a druhé se vztahuje $\mathrm{k}$ tomu, co je samostatné a jaksi izolované jen $\mathrm{v}$ důsledku modálního rozlišení a jeho rozlišenost nemá v plnosti reálnou povahu. Nutno k tomu ovšem podotknout, že dvojitost př́stupu a potažmo dvojaký charakter modů není v žádném případě výsledkem nějaké naší libovůle či nahodilého zaujímání stanovisek. Naše mysl, jsouc rovněž modem, nemůže (leda snad nějakým zázrakem) odhodit svou přirozenost a nahradit dvojitost př́stupu jedním jediným hlediskem vztahujícím se a založeným v reálně nekonečném. Z něčeho takového se nelze vymanit, lze si to však uvědomit, což neznačí nic jiného, než uvědomění si primariátu onoho prvního př́stupu. To, že jsme nuceni pohybovat se v oné dvojitosti, se pak ukáže jako nevyhnutelné a odpovídající celkovému uspořádání. Dvojitost našeho pohledu je totiž odpovídající dvojitosti substanciality samotné. Naše poznání naplňuje řád se vším všudy.

7. Dvojitost našeho př́stupu k modům (a tedy, jak jsem se snažil ukázat, vyjádření dvojitosti substanciality samé) se nemůže neprojevit v tom, že samotná existence má dvojitou povahu. Jednak je to existence jako taková, plnohodnotná, jíž lze ztotožnit s věčností, nebot' je to vlastně věčné ,ppotěšeni'“ $z$ existování, a jednak je to kvazi-existence, tj. existence jakožto trvání, která opět není ničím jiným než způsobem vyjádření původní existence jako takové. Podobně jako v prrípadě modalit samotných i u existence, která se k těmto modalitám vztahuje, platí, že musí být velice přesně rozlišována od absolutně nekonečné existence, tj. věčnosti. Spíše by to však mělo být vyjádřeno poněkud jinak: Je třeba být si dobře vědom onoho rozlišení (znovu jako v předchozím komentáři připomínám, že toto rozlišení není nahodile vznikajícím deficitem našeho poznání, nýbrž je to vyjádření modální povahy naší mysli), protože jinak by mohlo dojít $\mathrm{k}$ tomu, že by byl narušen pojem substance a znehodnocen pojem modu. Naše mysl musí (přesněji řečeno může, je toho schopna, nebot' povětšinou je to pro ni velice obtížné) být schopna po všech stránkách odlišovat existenci od kvazi-existence, tedy věčnost od trvání.

8. Zdá se mi, že je právě zde nutno dobře rozumět spinozovském textu. V případě nekonečna absolutního, tj. věčnosti, resp. věčné existence, je vše vcelku (v mezích daných našemu chápání) zřejmé, a proto by pro nás nemělo nic obtížného na tom, abychom stále měli na zřeteli, že je to nekonečno jedinečné, homogenní, nedělitelné atd. Naproti tomu v př́padě trvání, tj. vymezitelné existence modů, je-li nekonečné (a my již víme, že nekonečné být může, avšak nevlastním způsobem), pak vzhledem $\mathrm{k}$ jeho povaze je možné ho považovat za dělitelné, nehomogenní, vícenásobné atd. a tedy také o něm uvažovat $\mathrm{z}$ hlediska relace větší -menší. (V př́ípadě jedinečného absolutního nekonečna je to přirozeně nesmyslné.)

Zde je manifestována přímá souvztažnost pojmu a toho, co je jím označeno. Pojem nekonečna ve vlastním smyslu nemůže být spojován $\mathrm{s}$ něčím, co je v nesmiřitelném rozporu s povahou absolutního nekonečna. Pokud se tak děje, je tento pojem okamžitě destruován. Oproti tomu 
pojem nekonečna v nevlastním smyslu může být s něčím takovým beze sporu spojen. Je to tedy záležitost naprosto přesného rozlišování.

9. Předpoklad, že se prrímka skládá z bodů, může vzniknout $\mathrm{z}$ toho, že body př́mky jsou tak malé, že naše vnímání není schopno je rozlišit, a proto dochází ke korekci zkušenosti naším rozumem, jenž doplňuje, že to, co se našemu (nedokonalému) vnímání jeví jakožto souvislá, homogenní linie, je ve skutečnosti diskontinuitní struktura velejemných bodů. Je to analogické tomu, jak Spinoza objasňuje vznik tzv. transcendentální a universálních pojmů v naší mysli. „,V lidském těle se zřejmě vytváří najednou tolik představových obrazů (dejme tomu lidí), že sice schopnost představování zcela nepřevyšují, ale přesto ji převyšují natolik, že podrobnější rozdíly mezi jednotlivci (např́klad jejich barvu, velikost a jejich určitý počet atd.) si mysl nedovede představit. Představuje si přesně pouze to, v čem se všichni tito jednotlivci shodují, protože tím bylo tělo nejvíce podněcováno, jsouc tím totiž podněcováno každým jednotlivcem. To vyjadřuje pod názvem, „člověk“ a to přisuzuje nekonečnému počtu jednotlivců, protože není schopna - jak jsme řekli výše - představit si jejich určitý počet. “68

Je třeba si uvědomit, že počínaje antickým starověkem nejautoritativnějšś podání výměru př́mky - tj. Eukleidova definice - není v tomto směru směrodatná, nebot' zní: „Linea autem sine latitudine longitudo. “69 Nicméně už Heron Alexandrijský (zvaný Méchanikos, asi 1. st.n.l.) podal výklad a doplnění Euklidových definic, kde uvádí, že „linea“ nemá šiř́ku ani hloubku, vzniká, jestliže se bod pohybuje od shora dolů bez přerušení, skládá se z bodů a je vymezena body a představuje hranici plochy. “70

10. Pro dokreslení celé Spinozovy úvahy bude jistě vhodné ocitovat část z již uvedené poznámky k 15. tvrzení první knihy Etiky. Když holandský filosof uvedl to, co uvádí i dopise, dodává $\mathrm{k}$ tomu: „To vše bude zcela jasné každému, kdo umí rozlišovat mezi představivostí a rozumem, zvláště když si všimne, že hmota je všude táž a že její jednotlivé části jsou v ní rozlišeny jen potud, pokud ji chápeme $\mathrm{v}$ různých stavech. $Z$ toho plyne, že její části jsou rozlišeny pouze modálně a nikoli reálně.“"71

Mohu snad jedině dodat, že klíčem k porozumění je přesné rozlišování a za předpokladu jeho dodržení nemůže problém nekonečna vystoupit jako příliš obtížný, či dokonce neřešitelný. Naše představivost má jistou funkci a naše představy mají přsesně stanovený ontologický statut. Pokud je nezaměňujeme s realitou, potud nám není klíč k porozumění odepřen. Bohužel, jak ostatně sám Spinoza upozorňuje, není pro nás jednoduché zbavit se iluzí o své vlastní představivosti. Jsme prostě tělesní, až příliš tělesní, a to nám brání prohlédnout a uvědomit si př́lišnou „nadvládu představ“, která je sice v běžném každodenním životě funkční (ostatně odpovídá tomu, jak funguje ,ř́ád prŕírody či přirozenosti““), ale v prŕípadě snahy transcendovat každodennost selhává.

11. Spinozovo tvrzení, že míra, čas a číslo jsou pouhé pomocné prostředky představivosti, je tvrzení zásadní důležitosti. Ve filosofově mysli již bylo v té době pevně usazeno, i když o něm uvažoval i v trochu jiných souvislostech.. Svědčí o tom $\S 4$ první kapitoly první části jeho Metafyzických myšlenek, které pravděpodobně vznikaly řadu let před napsáním tohoto dopisu, kde uvádí: „Máme rovněž mody myšlení k vysvětlování věci, tj. $\mathrm{k}$ jejímu určování skrze srovnání s jinou věcí. Mody myšlení, pomocí kterých to provádíme, se nazývají čas, číslo, a míra a snad jsou ještě jiná. Čas slouží k vysvětlení trvání, číslo k vysvětlení nespojitého množství a míra k vysvětlení spojitého množství. “72 Kromě toho je možno vzpomenout i $§ 3$ čtvrté kapitoly první části (byt' je zde řeč pouze o času), kde je uvedeno: „Proto čas není stavem 
věcí, nýbrž je čistým modem myšlení neboli, jak jsme již řekli, rozumovým jsoucnem. Je to totiž modus myšlení sloužící k vysvětlení trvání. Musí zde být poznamenáno to, co bude užitečné později, až budeme hovořit o věčnosti, totiž že trvání je chápáno jako větší či menší a jakoby složené z částí a že je atributem existence a nikoli esence." ${ }^{\text {"73 }}$ Nelze však opominout jednu podstatnou okolnost. V dopise Spinoza hovoří o ,čísle, míře a času“ výhradně jako o „prostředcích či pomocných prostředcích představivosti“", kdežto ve starších textech píše o tomtéž jako o „modech myšlení“. Rozdílný způsob označení je zřejmě opodstatněn tím, že filosof měl při psaní dopisu neustále na zřeteli ono přesné odlišení toho, co si můžeme představit a myslet, od toho, co si můžeme pouze myslet. To je také smysl opravy v textu dopisu: „...míra, čas a číslo nejsou ničím jiným než mody myšlení, nebo spíše představování.“

12. Celá tato pasáž má podstatný význam. Již v Metafyzických myšlenkách filosof vymezil představování (imaginaci) jako „vnímání stop, které v mozku zanechal pohyb duchů vyvolaný ve smyslech vnějšími předměty..."74 (Termín „duchové, resp. živočišní duchové“, který Spinoza použil i v Krátkém pojednání o Bohu člověku a jeho blahu ${ }^{75}$ a nahradil posléze v Etice pojmem ,tekutých částic“776, sloužil k označení látkového nositele toho, čemu dnes říkáme „nervové vzruchy“،) Ve vztahu k tomu platí, že je-li něco prostředkem představování, pak je to nutně vázáno právě $\mathrm{k}$ takovému vnímání stop vyvolávaných v těle (smyslech, mozku) vnějšími podněty a je to tím také limitováno. Nevztahuje se to žádným způsobem k tomu, co z vnějšího světa stopu vyvolalo, ale právě k té stopě, resp. k jejímu vnímání.

Zkusme to uvážit následujícím způsobem. Představit si nekonečno $\mathrm{v}$ jeho aktualitě by znamenalo mít možnost vnímat stopu tohoto aktuálně nekonečného v našem mozku. Stopa aktuálně nekonečného by $\mathrm{v}$ sobě nesměla mít ani zbla $\mathrm{z}$ konečné přirozenosti toho, $\mathrm{v}$ čem byla zanechána, avšak to je zhola nemožné, nebot' by muselo naše tělo (smysly, mozek) nejprve odvrhnout svou konečnou přirozenost. Jinak řečeno představit si aktuálně nekonečné v žádném př́padě nelze! Avšak postupme dále: $\mathrm{K}$ tomu, abychom si mohli představovat, tj. abychom mohli dobře vnímat stopy, má naše mysl k dispozici určité instrumentarium. O něm Spinoza v Pojednání o nápravě rozumu uvádí: „A rovněž tak rozum si vytvárí svou vrozenou silou rozumové nástroje, kterými získává další síly $\mathrm{k}$ jiným rozumovým činnostem, a $\mathrm{z}$ těchto činností jiné nástroje neboli mohoucnosti k dalšímu zkoumání...."77 Nástroje (prostředky) vytvářené rozumem jsou ryzími „entia rationis“, tj. pomyslnými jsoucny, jež jsou svým ontologickým statutem vázána pouze a výhradně k lidské mysli samé, a to přesto, že celé instrumentarium není ryzí vrozenou záležitostí, nýbrž konstituuje se v celé své rozmanitosti v činnosti rozumu pracujícího $\mathrm{s}$ idejemi reálných jsoucen. Směšovat je s tím, co je reálné (řekněme „objektivní“) je naprosto nepřípustné. Jsou to nástroje, kterými pojímáme to, jak se zaznamenává vnější svět $\mathrm{v}$ našem těle, a nelze proto být přesvědčen o tom, že mohou být jaksi „objektivizovány“. V tom, jak svět pojímáme a vysvětlujeme, svět sám netvoříme, tvoříme pouze jeho určité pojetí. Naší vlastní nekritičností a nesoudností a nedostatečnou pečlivostí dochází $\mathrm{k}$ poměrně častému směšování obojího a dokonce i $\mathrm{k}$ záměně jednoho za druhé. Pomocné prostředky představivosti a rozumu jsou zaměněny za reálná jsoucna. Stopy, zanechané v naší konečné tělesnosti, jsou zpracovány tak, že snadno podlehneme iluzi o tom, že výsledek takového zpracování je totožný se skutečností samou. Na základě toho je pak výsledkem zpracování konečné stopy, kterou v nás zanechává aktuálně nekonečné, záměna aktuálně nekonečného za představu nekonečného, která je vázána na takové prostředky, jakým je například číslo. To v konečném důsledku vede až k tomu, že samotné prostředky (číslo) jsou považovány (přesněji představovány) jako skutečně nekonečné. Ale to už je zcela chybný úkon. Samozřejmě my jsme zvyklí si všechno před-stavovat. Toto „před-sebe-stavění“ je ukotveno $\mathrm{v}$ naší konečné přirozenosti a náleží $\mathrm{k}$ obecnému řádu př́rody (přirozenosti). To ovšem neznamená, že jsme jakýmisi „zajatci představivosti“. Máme totiž také rozum, resp. intelekt 
(chápavost), který nám umožňuje iluzívnost představ prohlédnout. Prostřednictvím něho pro nás není rozlišení nekonečna (řečeno hegelovsky) „špatného“ a „pravého“ zapovězenou záležitostí. (K tomu srov. Gueroultovy charakteristiky uvedené v komentáŕi 4.)

Pokusme se ještě jiným způsobem ${ }^{78}$ poodhalit možné významy spinozovských úvah o nekonečnu. Jsou totiž takového rázu, že nás dovádí k tomu, abychom si uvědomili, že naše schopnost rozlišit nekonečné v pravém, absolutním smyslu od nekonečného konstituovaného v našem pojetí otevírá před námi další perspektivy. A jsou to (sit venia verbo) útěšlivé perspektivy, v nichž se vynořuje smysl. Pravé, absolutní nekonečno totiž osmysluje, aniž by samo smysl mělo. Je totiž čímsi, co nemá tvar, ale co dělá spolu s našimi poznávacími mohutnostmi tvar. Je totiž čímsi, co samo nebloudí, ale nás nechává nádherně bloudit. Je totiž čímsi, co samo nemá nic z toho, čím my se ho zmocňujeme (je ne-bytím něčeho takového), ale v našem pojímání se ve všechno proměňuje. Je totiž čímsi, co samo jsouc nestvořené, nechává se stvořit $\mathrm{v}$ nás ( $\mathrm{v}$ naší mysli) a tím nechává nás stvořit sama sebe.

Není větší útěchy než „útěcha ze smyslu“ a pokud si dostatečně uvědomujeme nutnost onoho přesného rozlišování nekonečného, pak se dostáváme k „útěše z pravého nekonečna“, které pak přestává být něčím hrozivým, děsivým a bezútěšným. Obrazně vyjádřeno obracet $\mathrm{k}$ němu duchovní zrak znamená dobro nejvyšší. Jak říká Spinoza: „Summum mentis bonum est Dei cognitio. ${ }^{679}$

13. Spinoza uvádí v této pasáži dopisu myšlenku, která je po mém soudu nesmírně důležitá. Tato myšlenka zní: „,...povaha věci nemůže číslo snést [strpět] bez zjevného rozporu.“ („,...rei natura non sine manifesta contradictione numerum pati potest.") Je to myšlenka, kterou lze interpretovat různými způsoby $\mathrm{a} \mathrm{v}$ různých rovinách, nicméně domnívám se, že to nejdůležitější, čeho bychom si měli povšimnout, je to, že Spinoza, často chápaný jako zosobnění matematizujícího (což bývá chápáno ve smyslu ztotožnění matematické = číselné, resp. numerické) stylu myšlení, nekompromisně zastává názor o nutné omezenosti, nedostatečnosti (deficitu) čísla (počtu) při vysvětlování a určování věcí, přičemž v případě věci aktuálně nekonečné číslo (počet) selhává naprosto. Pro všemožné „počtáře“ (kalkulátory) je to jistě nemilá a zcela nepřijatelná myšlenka, avšak pohyb matematického myšlení samotného v tomto směru dal holandskému filosofu za pravdu. Ostatně teprve v okamžiku, kdy si začal člověk uvědomovat nutnost rozlišování, o kterém Spinoza píše ve svém dopise, byl schopen si uvědomit, že takové pomocné prostředky představivosti, jakým je číslo (počet), nemohou $\mathrm{v}$ žádném př́padě dopomoci $\mathrm{k}$ alespoň nějakému uchopení a porozumění aktuálnímu nekonečnu, nebot' jejich užití musí nutně dospět k neřešitelnému konfliktu s povahou této věci samé.

K něčemu takovému dospěl svého času matematik George Cantor, který si posléze stanovil za svůj úkol nalézt (a dokázat, že existují) takové „,pomocné prostředky“, kterými lze o aktuálním nekonečnu přemýšlet bezrozporně. I on sice takové prostředky nazýval „čísly“, avšak stále upozorňoval na to, tato „nekonečná čísla“ mají úplně jiné vlastnosti než čísla používaná k určování a vysvětlování konečných věcí vezdejšího světa. Kardinální číslo množiny celých čísel $\boldsymbol{\aleph}$, kardinální číslo množiny reálných čísel $\boldsymbol{c}$, absolutní nekonečno $\boldsymbol{\Omega}$ - to všechno jsou pomocné prostředky, jež nemají s čísly vezdejšího světa žádné společné vlastnosti.

G. Cantor sám rozlišoval trri podoby projevu aktuálního nekonečna: ${ }^{80}$

1. V Bohu, v př́rodě tvořící (in natura naturans), kde se nazývá absolutní.

2. ve vnímatelných věcech, $v$ prírodě stvořené (in concreto seu in natura naturata)

3. v „nekonečných číslech“ (in abstracto), kde může být zachyceno lidským myšlením.

$\mathrm{V}$ tomto ohledu použil německý matematik dokonce rozlišení velice podobné tomu, které zohledňoval i B. Spinoza. ${ }^{81}$ 
14. B. Spinoza přidal na konec svého listu doplňující (podal ji „mimochodem“) poznámku o jistém způsobu dokazování existence Boha, $\mathrm{v}$ němž figuruje teze o existence aktuálního nekonečna. Je potřebné si uvědomit smysl a účel této poznámky. Holandský filosof, zdá se, chtěl upozornit svého přítele na to, že ono neporozumění nekonečnu způsobené nedostatečným rozlišováním má své závažné konsekvence i v této oblasti a tedy že napravením chybného postupu může být ověřeno, jak je důležité orientovat se dobře $\mathrm{v}$ otázkách týkajících se nekonečna, reps. přesněji vyjádřeno aktuálního nekonečna.

B. Spinoza kritizuje tehdejš́ stoupence aristotelské filosofie (neoperipatetiky) ${ }^{82}$ za to, že špatně pochopili důkaz starých peripatetiků. Pomineme-li problematiku toho, s jakými názory vlastně Spinoza polemizuje ${ }^{83}$, pak smysl celé dodatečné poznámky tkví v předvedení toho, že popření (absurdita) aktuální existence nekonečna (nekonečného sledu příčin) není a ani nemůže být něčím, co dodává důkazu Boží existence argumentační sílu. Pokud má mít nějaký takový důkaz, o jakém je v doplňující poznámce řeč, opravdovou sílu či moc (vis), pak to může být jedině v premise, jež tvrdí, že věci ne-nutné musí mít za svůj ,základ bytí“, resp. za to, co jim dodává ono „být určen k existenci“ (determinari ad existendum) pouze věc „svou přirozeností nutnou“, tj. věc, která je pouze „způsobující“, „přičiňujíci““ (causa) a v žadném případě není „způsobená““, „Zapř́ičiněná“ (causata).

Pokud bychom falešně podstrčili jinou premisu, totiž že věci ne-nutné nejsou založeny ve věci svou přirozeností nutné, pak samozřjmě lze dospět postupem „reductio ad absurdum“ $\mathrm{k}$ tomu, že aktuální existence nekonečného sledu prríčin je absurdní. A právě s takto falešně pochopeným vedením důkazu holandský filosof polemizuje a upozorňuje na jeho chybnost svého přítele.

Nutno ovšem na závěr poznamenat, že celé místo není př́iliš jasné ${ }^{84}$ a vyznívá jako poněkud „ve spěchu podaná poznámka na závěr“. K jistému časovému tlaku se ostatně Spinoza sám přiznává v posledním odstavci svého dopisu. 


\section{Poznámky a vysvětlivky:}

${ }^{1}$ První český překlad pořídil Josef Hrůša v roce 1932. Viz Spinoza, B.: Listy, Praha 1932, str. 169-175. Tento nový překlad byl pořízen z Gebhardtova kritického vydání spisů B. Spinozy. Viz Spinoza, B.: Opera I-IV, vol. IV, hrsg. von C. Gebhardt, Heidelberg 1924-1925, str. 52-62. Z téhož vydání je také přetištěno latinské znění dopisu. Vysvětlivky a poznámky se z valné části opírají o poznámkový aparát $\mathrm{C}$.

Gebhardta, viz cit. vydání, vol. IV, str. 390-391.

${ }^{2}$ Dovolil jsem si zde použít termínu, který užíval Karel Kosík v svých esejích. Viz Kosík, K.: Jinoch a smrt, Hynek, s.r.o., Praha 1994. Ostatně myšlenky K. Kosíka obsažené v této drobné publikaci jsou vůbec v pozadí některých pasáží tohoto úvodu.

3 Text dopisu byl poprvé vydán tiskem $\mathrm{v}$ rámci posmrtně vydaného souboru Spinozových děl: latinská verze Opera posthuma a holandská verze De Nagelate Schriften, oboje vydáno $\mathrm{v}$ Amsterdamu $\mathrm{v}$ roce filosofova úmrtí, tj. v roce 1677 . Originál tohoto dopisu měl být podle sdělení převzatého C. Gebhardtem (s odvoláním na J. van Vlotena a J. P. N. Landa) vydražen na knižní aukci $\mathrm{v}$ roce 1860 , kde ho získal pařížský knihkupec Durand. V soupisu aukčních položek je pod číslem 1716 uvedeno: Le même. (= Spinoza, B.de.) Pc. A. S.date. (tj.: Týž (=Spinoza, B.de.) Autografický kus. Bez data.) C. Gebhardt však uvádí, že pokud se jednalo o autografický kus bez signatury a data, pak to nemohl být původní exemplář dopisu odeslaného L. Meyerovi. Pravděpodobně to byl bud' Spinozův koncept dopisu, nebo nějaký opis pořízený (snad) filosofovou rukou. Není tedy ani úplně zřejmé, zda to byl skutečně originální autografický kus. Nicméně k pozdější rekonstrukci textu bylo možno použít také Leibnizův opis dopisu s vlastními kritickými poznámkami, který se nachází v Leibnizově pozůstalosti v knihovně Niedersächsischen Bibliothek

v Hannoveru Ostatně proto také C. Gebhardt otiskl ve své edici Spinozova dopisu společně obě verze, tj. verzi z Opera posthuma i Leibnizův opis.

$4 \quad$ V prvním vydání Spinozovy korespondence, které bylo obsaženo v posmrtném vydání filosofových spisů (viz Opera posthuma, Amsterdam 1677), je dopis označen jako Epistola XXIX.

5 V Opera posthuma je na tomto místě pouze zkratka L. M. P. M. Q. D., tj. Ludovico Meyer Philosophiae Medicinaeque Doctor.

6 Složené závorky odpovídají dodatkům editora kritického vydání Carla Gebhardta. Výrazy vyznačené hranatými závorkami jsou doplňky překladatele, které mají dodat překladu větší srozumitelnost a jasnost.

${ }^{7}$ Podle ruského vydání Spinozových spisů se se vší pravděpodobností jedná 0 P. Ballinga, který na počátku roku 1663 navštívil B. Spinozu v Rijnsburgu. (Viz Spinoza, В.: Избранные произведения, tom II, Moskva 1957, str. 680.)

${ }^{8}$ Data jsou uvedena v De Nagelate Schriften a do latinské verze vložena C. Gebhardtem.

9 Tento nadpis obsahuje pouze holandská verze Spinozových posmrtně vydaných spisů (viz De Nagelate Schriften, Amsterdam 1677.). Jeho překlad zní: $O$ povaze nekonečna. Spinoza sám označil v dopise Waltheru E. von Tschirnhausovi z 5. května 1676 svůj list za ,dopis o nekonečnu“ (Epistola de Infinito). Viz Listy, str. 184, a Opera, vol. IV, str. 332. (V holandské verzi posmrtně vydaných děl ovšem je místo tohoto označení uvedeno: „....in een brief, aan L.M. geschreven....“. Volně přeloženo: „V dopise napsaném L.M. (L.Meyerovi)“.) 
10 V De Nagelate Schriften je použita formulace ,om dat zy geen onderscheit (Distinctio)...gemaakt hebben“. (Volně přeloženo: „že nedělali žádný rozdíl /distinctio/“.)

11 Holandská verze posmrtně vydaných Spinozových děl má (podobně jako Leibnizův opis dopisu ji obsahuje v latinském jazyce: „,...sive determinatum sit..") vsunutou vložku: ,en dit, van 't welk, schoon het bepaalt /Determinatum/ is, schoon wy..." (Volně přeloženo: ,... a toto je tak zcela určeno, a my...")

12 Tvrzení obsažené $\mathrm{v}$ závorce, které odpovídá v originále dopisu výrazu ,invitâ latinitate", má smysl pouze ve vztahu $\mathrm{k}$ latinskému jazyku. Jedná se o to, že Spinoza se zde omlouvá za výraz, který neodpovídá gramatickým pravidlům klasické latiny, tj. za výraz ,fruitio essendi““, zejména pak za mluvnický tvar ,essendi“", což je genitiv gerundia od slovesa ,esse“" (být). V klasické podobě latinského jazyka totiž sloveso „esse“ nemělo, resp. netvořilo tvar gerundia. Tento tvar se objevil jako uměle vytvořený (analogicky podle toho, jak je tvořen $u$ jiných sloves) až ve středověku. Používal ho například sv. Tomáš Akvinský, viz jeho výraz ,actus essendi“. Nicméně přes používání ve filosofických či teologických textech byl i později tento tvar vnímán jako př́liš uměle vytvořený a odporující latinské gramatice.

13 Místo poslední části souvětí je $\mathrm{v} D e$ Nagelate Schriften uvedeno: , En op dat dit te lichtelijker zou geschieden, zo zal ik eerst..." $\mathrm{s}$ prrímým pokračováním $\mathrm{v}$ dalším odstavci. (Volně přeloženo: „A aby se ti to stalo jasnějším, tak budu nejprve...")

${ }^{14}$ Ve verzi dopisu z Opera posthuma jsou slova Substantia, Modi, Æternitas, Duratio, Tempus, Censura, Numerus, Intellectus, Imaginatio často psána $\mathrm{s}$ velkými počátečními písmeny. Vzhledem k tomu, že v Leibnizově opisu tato velká písmena nejsou pravidlem, není zřejmé, zda se jedná o Spinozovu úpravu či nikoli. M. Gueroult se nicméně domníval, že tato „kapitalizace“ některých slov je dílem filosofovým. Viz Gueroult, M.: Spinoza, vol. I, AubierMontaigne, Paris 1968, Appendix IX, str. 500-528. Citováno dle Gueroult, M.: Spinoza's letter on the Infinite, v: Spinoza. A Collection of Critical Essays, ed. M. Grene, Notre Dame, Indiana 1973, str. 184.

15 V De Nagelate Schriften je pořadí věčnosti (Eeuwigheit) a modu (Wijze) obráceno.

${ }^{16}$ V Leibnizově opisu je místo „Naturæ“ uvedeno ,materiæ“.

17 Celý tento odstavec se téměř doslova shoduje s částí poznámky $\mathrm{k} 15$. tvrzení první knihy Etiky. Viz Spinoza, B.: Etika, cit. vyd., str. 74.

18 Holandská verze zde uvádí obrácené pořadí: „veelvoudig /Multiplex/, en uit delen te zamengezet." (Volně přeloženo: „...mnohonásobná a složená z částí.“)

19 V De Nagelate Schriften je doslova uvedeno: ,... gelijk ik, zo ik my niets vergis, alreê genoech betoogt heb." (Volně přeloženo: ,...podobně, jak jsem ti již, pokud mne pamět' nemýlí, dostatečně prokázal.“)

${ }^{20}$ Poslední část souvětí v Leibnizově opisu zní: „,...et à nullo absurdo, quantumvis turpissimo cavendo.“ To lze přeložit: „...a žádným uchráněním se od nesmyslností, ba od těch největších ohavností.“

21 V holandské verzi je za jménem Charybdy ještě dodatek: „dat is van quaat tot erger", což doslova znamená ,že to je od desíti k pěti““. Volně přeloženo: „tj. od zlého $\mathrm{k}$ horšímu“.

22 Skylla byla mořská obluda (dcera nestvưrného mořského boha Forkýna a 
bohyně divoké síly mořských vln Krataie) se šesti psími hlavami a dvanácti nohami, která žila v hluboké jeskyni v Messinské úžině mezi Sicilií a Kalábrií a chytala všechno živé, co jí přišlo na dosah. Naproti této jeskyni žila druhá mořská obluda Charybdis, která třikrát denně vpíjela a chrlila vodu. Právě blízkost a spoluexistence obou mořských nestvůr v Messinské úžině představovala smrtelné nebezpečí pro každého mořeplavce. Proto se už ve starověku jména obou bájných oblud stala synonymem záhuby. Legenda byla později přenesena $\mathrm{i}$ do středověké literatury. Spinoza pravděpodobně parafrázoval verš středověkého básníka Gautiera de Lille: „Incidis in Scyllam, cupiens vitare Charybdim." (Chtěje uniknout Charybdě, propadneš Skylle.) (Srov. cit. rus. prreklad, str. 681.)

${ }^{23}$ Ve výraze „... Infinitum actu negârunt...“ lze slovo ,actu“ vztáhnout ke slovesu a překládat: „,..skutečně popřeli nekonečno...". Tak např́klad překládal uvedené místo J. Stern: „...die Unendlichkeit in der Wirklichkeit geleugnet haben." (Viz Spinoza, B.: Briefwechsel, Reclam, Leipzig (nedat.), str. 51) Podobně překládali angličtí př́ekladatelé R. Elwes a Wulf: „...have actually denied the infinite.“, eventuelně ,...actually denied that there is an Infinite." C. Gebhardt se ovšem přiklonil $\mathrm{k}$ tomu vztáhnout slovo „actu“ ke slovu „Infinitum“ a překládat „popřeli skutečně nekonečné“. (Viz cit. rus. překlad, str. 681) Já jsem ve svém prrekladu (podobně jako J. Hrůša, viz Listy, str. 173) rovněž spojil slovo ,actu“ se slovem „Infinitum“.

${ }^{24}$ M. Gueroult upozornil ve své studii na to, že se běžně traduje nesprávný překlad výrazu ,inæqualitates spatii“ jako ,unequal distance“, tj. „nerovné vzdálenosti“, přestože to musí být přeloženo jako ,inequalities of distance“, tj. jako „,nerovnosti (různosti) vzdálenosti“. (Viz Gueroult, M.: cit. dílo, str. 206.) Nesprávným způsobem přeložil uvedenou pasáž i G. W. F. Hegel ve svých Přednáškách o dějinách filosofie: „die ungleichen Abstände des Raumes“, tj. „nestejné prostorové vzdálenosti“. (Viz Hegel, G. W. F.: Dějiny filosofie, sv. III, Academia, Praha 1974, str.267.) Jako př́klad Hegelova následovníka uvádí M. Gueroult francouzského překladatele Ch. Appuhna, který uvedené místo přeložil „la somme des distances inégales“ (,suma nestejných vzdálenostíc). (Viz Gueroult, M.: cit.dílo, str. 206.) V citovaném překladu J. Sterna (str. 51) je uvedeno ,alle Ungleichheiten des Raumes“, tj. „všechny nerovnosti prostoru“. Tentýž způsob překladu použil i J. Hrůša. (str. 173.) Ruský překlad se opřel spíše o hegelovskou tradici: „совокупность неравных расстояний“ (tj. „souhrn nestejných vzdáleností'“, viz. cit. rus. překlad, str. 427.)

${ }^{25}$ I na tomto místě M. Gueroult (viz cit. dílo, str. 206) upozorňuje na běžně tradovaný nesprávný překlad pasáže , Nam quantumvis parvam ejus portionis capiamus,..." Bývá to překládáno slovy „however small we may conceive it..." (tj. ,za jakkoli malé to smíme považovat"), kde oním „it“ („to“) je označen prostor umístěný mezi dvěma kruhy. Správný překlad má podle francouzského autora znít: „However small be the part that we may consider of the interposed space." („Jakkoli malá je část, kterou můžeme uvažovat $\mathrm{z}$ prostoru umístěného mezi [dvěma kruhy].“)

26 V De Nagelate Schriften je uvedeno pouze: ,..tusschen twee kringen AB gestelt.“ (Volně přeloženo: „...umístěno mezi dva kruhy AB.“)

${ }^{27}$ Lze se pouze hypoteticky domnívat, které neoaristoteliky měl Spinoza na mysli. Snad by se mohlo jednat o některé učitele $\mathrm{z}$ leidenské university té doby, např̀. F. Burgersdijka nebo A. Heereboorda. Je pravdou, že hlavní představitel neoaristotelismu na počátku novověku F. Suarez (pro uvedené autory jedna 
z duchovních autorit) skutečně považoval nekonečný regres příčinných řetězců za nemožný. (Viz Krop, H. A.: Natural knowledge of God in neo-Aristotelianism. The reception of Suarez'version of the ontological argument in early seventeenth century Leden., v: Franco Burgersdijk (1590-1635). Neo-Aristotelianism in Leiden, Rodopi, Amsterdam 1993, str. 6783.

${ }^{28}$ Holandský filosof má zřejmě na mysli Chasdaje Kreskase (1340-1410), rabiho ze španělské Zaragozy, který se pokusil zejména ve spisu Boži světlo (Or Adonaj, 1405) položit nové základy židovského myšlení oproštěné od vlivu aristotelismu. Přes svi̊j odklon od intelektualismu podal důkaz existence Boha, o kterém se Spinoza zmiňuje. (Blíže viz. např. Hamoun, M.-R.: Židovské osvícenství mezi Córdobou a Berlinem, Volvox Globator, Praha 1998, str. 214 a další.)

${ }^{29}$ Zřejmě se jedná o Spinozovu parafrázi Kreskasova důkazního postupu. Navíc jak upozornil H. A. Wolfson (Viz Wolfson, H., A: The Philosophy of Spinoza I-II, Harvard University Press 1962, str. 195 a násl.), Spinoza se neorientoval dobře v historickém pozadí tohoto důkazu. Jednalo se totiž o Kreskasovu modifikaci Avicennova důkazu v tom ohledu, že $z$ něj bylo eliminováno aristotelské popření nekonečného sledu prŕčin a následků. $\mathrm{V}$ tomto smyslu se nemohlo jednat o důkazní postup „starých peripatetiků“, nebot' Kreskasův postup je s ním v příkrém rozporu. (Zdá se, že holandská verze $D e$ Nagelate Schriften už tuto skutečnost zohlednila - viz pozn. č.31.) H. A.Wolfson uvádí toto znění Kreskasova důkazu:

„Každý sled možných jsoucen musí mít příčinu, která je nutným jsoucnem.

Svět je sledem možných jsoucen.

Proto svět musí mít příčinu, která je nutným jsoucnem.“" (cit. dílo, str. 196)

Kromě toho však je Wolfsonově díle uvedena i originální pasáž z Kreskasova spisu Or Adonaj: „Whether causes and effect are finite or infinite, there is no escape from the conclusions that there must be something which is the cause of all of them as a whole, for if there nothing but effect, those effect would have only possible existence per se and would thus need something to cause the preponderance of their existence over their non-existence. But that which would bring about this preponderance of their existence would be the cause of those effect, and that is what is meant by God.“ (cit. dílo, str. 196-197, poznámka 2) (Volně přeloženo: „At' už jsou prŕččiny a účinky konečné nebo nekonečné, nelze nijak uniknout prijetí závěru, že musí existovat něco, co je př́íčinou všech [příčin a účinků] jako celku, protože kdyby neexistovalo nic než účinky, měly by tyto účinky pouze možnou existenci per se a potřebovaly by tedy něco, co by bylo př́činou převahy jejich existence nad jejich neexistencí. Ale to, co by způsobilo tuto převahu jejich existence, by bylo příčinou těchto účinků, a [tedy] tím, za co je považován Bůh.“")

30 De Nagelate Schriften mají na tomto místě slovo „opgelost“ (Dissolvi), tj. „rozluštěný, vyřešený““.

${ }^{31}$ Holandská verze neobsahuje ,recentiores“.

32 Místo „sic sonat“ je v De Nagelate Schriften uvedeno: ,...luid de zelfde heel anders; dewijl hy dus bewijst." (Volně přeloženo: „,...zní o tomtéž úplně jinak, ježto dokazuje takto:...")

33 V latinské verzi Opera posthuma je „Atque“. C. Gebhardt opravil na „Atqui“, aby to lépe odpovídalo sylogismu. Stejnou opravu provedli již J. van Vloten a J. P. N. Land.

34 I v tomto př́padě lze slovo ,actu“ vztáhnout ke slovesu „dari“ nebo ke slovu „Infinitum“. Viz výšse poznámku č. 23. Podobně jako $\mathrm{v}$ předchozím případě $\mathrm{i}$ zde jsem ho vztáhl ke slovu „Infinitum“. 
35 Tato dodatečná oprava obsažená v hranaté závorce byla dodána proto, že jinak nedává ona věta dobrý smysl (viz poznámku č. 36). Navíc se tento dodatek opírá o opravu Leibnizovu, kterou v Gebhardtově edici neobsahuje základní text Leibnizova opisu, ale $\mathrm{v}$ poznámce ji editor textu uvádí. Závěrečná část souvětí tak v Leibnizově podání vypadá takto: „...quòd supponant sc. quæ sua natura non necessariò existunt, non determinari * $[+$ nisi +$]$ à re sua natura necessario existente." Podle sdělení $H$. Bergera $z$ Hannoveru označoval Leibniz právě tímto způsobem své vlastní komentáře a poznámky vkládané do cizích textů. (Viz Klever, W.: cit. dílo, str. 116.)

36 C. Gebhardt uvádí, že holandský spinozovský badatel W. Meijer chtěl toto místo opravit bud' tím, že by po „supponatur" vložil „quod impossible sit", a nebo podle Leibnizova opisu za ,ad existendum“ vložil „nisi“. Oba dva způsoby čtení textu lze interpretovat podle německého editora ve stejném smyslu: Spinoza nalézá hodnotu argumentu v přijetí závislosti konečného na nekonečném. To je postaveno proti smyslu interpretace, který byl tradován ve trojí redakci, totiž že ze zjištěné nesmyslnosti Spinoza odvozuje, že žádná závislost tohoto druhu neexistuje. V závěru poznámky pak dodává: „Man wird darum an der überlieferten Leseart festhalten dürfen." (Opera, vol. IV, str. 391.) („Je možné se proto tradovaného způsobu čtení držet.“/!/)

Pro srovnání překlad uvedené pasáže od J. Hrůši zní: „Síla důkazu není tedy v tom, že je nemožné, aby $\mathrm{v}$ skutečnosti bylo nekonečné nebo nekonečný postup prŕíčin do nekonečna, nýbrž jen $\mathrm{v}$ tom, že se předpokládá, že věci, které vedle své přirozenosti nejsou nutné (tj.nemusí býti), nemohou býti $\mathrm{k}$ jsoucnosti určovány ničím, co vedle své prrirozenosti zde nutně je.“" (Listy, str. 175.)

Celý problém je přece jen poněkud složitější a kolem Spinozovy formulace starého důkazu existence Boha se vedou diskuse. V jistém smyslu se pokusil celou záležitost shrnout současný holandský spinozovský badatel W. Klever. (viz Klever, W.: Actual infinity: A note on the Crescas-passus in Sopinoza's letter (12) to Lodewijk Meijer, v: Studia Spinozana, vol. 10 (1994), str. 111-121.) Ten poněkud koriguje editorské poznámky C. Gebhardta. Předně vyslovuje podiv nad poslední větou Gebhardtovy poznámky (viz předchozí odstavec), kterou považuje za nepochopitelnou! (Viz str. 116.) Dále upozorňuje na to, že W. Meijer ve svém překladu Spinozovy korespondence $\mathrm{z}$ roku 1897 (Spinoza, B.: Brieven, vertaald door W. Meijer, Van Looy, Amsterdam 1897) navrhl opravu původního textu, v jejíž stopách jde i vydání holandského překladu Spinozových dopisů z roku 1977 (Spinoza, B.: Briefwisseling, vertaald door $F$. Akkerman e.a., Wereldbibliotheek, Amsterdam 1977), v němž je provedena tato oprava: „...sed tantum in eo (quod impossible sit), quod supponatur..." (viz Klever, W.: cit. dílo, str.116.) Věta pak ovšem působí poněkud šroubovaně a latinsky „nezvykle“. Někteří modernější prrekladatelé (Spinoza, B.: Collected Works, transl. E. Curley, University Press, Princeton 1985; Spinoza, B.: Oeuvres complétes, trad. R. Misrahi, Edition Pléiade, Paris 1954) toto místo přeložili doslova, jiní využili Leibnizovu korekci. (Spinoza, B.: Correspodencia, tr. A. Dominguez, Bolsillo, Madrid 1988.) Klever sám vyslovil hypotézu (cit. dílo, str. 114), že ono sporné „non“ se do textu vydaném v Opera posthuma dostalo chybou opisovače dopisu, který byl zřjejmě pomýlen tím, jak B. Spinoza užíval latinského slovesa „supponere“, eventuálně substantiva „suppositio“, ve smyslu „nesprávně předpokládat“, resp. „neoprávněný předpoklad“ či „nesprávná hypotéza“. Proto zřejmě podvědomě dosadil do následující věty nu negaci. $Z$ toho důvodu se $\mathrm{W}$. Klever domnívá, že je nutno text dopisu z Opera posthuma korigovat $\mathrm{v}$ tom smyslu, že ono sporné „non“ bude vypuštěno. 
K tomu lze dodat, že ono ,non“ by dávalo dobrý smysl v situaci, kdy by byl výraz „quod supponatur“ př̀ložen skutečně doslova a v duchu Spinozova užívání tohoto latinského slovesa, totiž ,že je podstrčeno, nastrčeno, podvrženo" a nikoli s převažujícím pozitivním významem „se předpokládá“. Celý překlad závěrečné části by pak zněl: „Pročež síla argumentu nespočívá $\mathrm{v}$ tom, že je nemožné, aby bylo dáno aktuálně nekonečné nebo nekonečný sled příčin, nýbrž toliko $\mathrm{v}$ tom, že je zde podvrženo [podstrčeno], že věci, které neexistují nutně ze své přirozenosti, nejsou určeny k existování věcí existující nutně ze své přrirozenosti.“

Jak vyplývá z textu překladu a z následující poznámky, i já jsem se však ve svém př̀kladu držel Leibnizovy korekce.

37 V Leibnizově opisu závěrečná část souvětí zní: ...quòd supponant sc. quæ sua natura non necessariò existunt, non determinari ad existendum à re sua natura necessariò existente.“ ${ }^{\prime} \mathrm{tj}$. ,...že předpokládají, že věci neexistující nutně ze své přirozenosti nejsou k existování určeny věcí ze své přirozenosti nutně existující.")

${ }^{38}$ Místo závěrečných vět je v De Nagelate Schriften pouze ,...enz.Vaar wel,...“ (,Sbohem...")

${ }^{39}$ Viz Garrett, A., V.: Meaning in Spinoza's Method, University Press, Cambridge 2003, str. 61. Garrett doslova píše: „Spinoza began a letter to his friend Meyer by announcing the singularity of his discovery, which he took great pride..."

${ }^{40}$ Spinoza toto pojednání napsal přibližně pět let před napsáním svého dopisu L. Meyerovi. (K dataci viz blíže Hemelík, M.: Na cestě $\mathrm{k}$ pravdivému poznání aneb několik marginálií ke Spinozovu metodickému spisku, v: Spinoza, B.: Pojednání o nápravě rozumu, Filosofia, Praha 2004, str. 15 a násl.)

41 Spinoza, B.: Pojednání o nápravě rozumu, cit. vyd., str. 75.
${ }^{42}$ Tamtéž.

43 Spinoza, B.: Etika vyložená způsobem uživaným v geometrii, přel. K. Hubka, Svoboda, Praha 1977, str. 56.

${ }^{44}$ Tamtéž.

45, „..Bohem rozumíme bytost nanejvýš dokonalou a naprosto neomezenou..." (Spinoza, B.: Listy, cit. vyd., str. 107.)

${ }^{46}$ Spinoza, B.: Etika, cit. vyd., str. 69.

${ }^{47}$ Tamtéž, str. 56.

48 Spinoza, B.: Metafyzické myšlenky, bilingva, přel. M. Hemelík, Filosofia Praha 2000, str. 53.

${ }^{49}$ Spinoza, B.: Etika, cit.vyd., str. 56.

${ }^{50}$ Gueroult, M.: cit. dílo, str. 185 a násl.

51 „My však nebudeme tvrdit, že všechno, $\mathrm{v}$ čem nemůžeme $\mathrm{v}$ nějakém ohledu objevit hranici, je nekonečné, ale budeme to považovat za neomezené.“ (Descartes, R.: Principy filosofie, bilingva, přel. P. Glombíček a T. Marvan, Filosofia, Praha 1998, str. 33-35.)

${ }^{52}$ Gueroult, M.: cit. dílo, str. 185.

${ }^{53}$ Spinoza, B.: Etika, cit. vyd., str. 189.

${ }^{54}$ Tamtéž.

${ }^{55}$ Tamtéž, str. 131.

${ }^{56}$ Tamtéž, str. 68.

57 Tamtéž, str. 73.

58 Latinské slovo „numerus“ znamená „číslo, počet, množství“, kteréžto významy Spinoza ve svém textu plně využívá.

59 Spinoza, B.: Pojednání o nápravě rozumu, cit. vyd., str. 109. 
${ }^{60}$ Tamtéž, str. 111.

${ }^{61}$ Spinoza, B.: Metafyzické myšlenky, cit. vyd., str. 47.

${ }^{62}$ Spinoza, B.: Etiky, cit. vyd., str. 143.

${ }^{63}$ Gueroult, M.: cit. dílo, str. 191 a násl.

${ }^{64} \mathrm{~V}$ raných i pozdějších textech a rovněž ve své korespondenci používal Spinoza všechny uvedené (a popř́ípadě i další) termíny k označení božského jsoucna. Stačí pečlivě porovnat text Pojednání o nápravě rozumu, Krátkého traktátu o Bohu, člověku a jeho blahu, Etiky, Traktátu teologickopolitického i Rozpravy politické a jednotlivých dopisů.

65 Viz Vopěnka, P.: Podivuhodný květ českého baroka, Karolinum, Praha 1998, str. 183.

${ }^{66}$ Spinoza, B.: Etika, cit. vyd., str. 169-170.

${ }^{67}$ Viz Spinoza, B.: Etika, cit. vyd., str. 5869.

${ }^{68}$ Spinoza, B.: Etika, cit.vyd., str. 154.

${ }^{69}$ Citováno dle Euclidis Elementa, edidit et latine interpretans est I. L. Heiberg, Leipzig 1883 na internetových stránkách http://www.xtec.es/.

${ }^{70}$ Viz Начала Евклида, kniha I-VI, přel. a komentáŕi opatřil D. D. MorduchajBoltovskij, Moskva 1950, str. 223.

${ }^{71}$ Spinoza, B.: Etika, cit. vyd., str. 74.
${ }^{72}$ Spinoza, B.: Metafyzické myšlenky, cit. vyd., str. 45.

73 Tamtéž, str. 79.

${ }^{74}$ Tamtéž, str. 47.

75 Spinoza, B.: Krátké pojednání o Bohu, člověku a jeho blahu, přel. F. Kalda, Praha 1932, str. 82.

${ }^{76}$ Spinoza, B,.: Etika, cit. vyd., str. 132.

77 Spinoza, B.: Pojednání o nápravě rоzити, cit. vyd., str. 61.

$78 \mathrm{~K}$ tomuto sledu myšlenek mne inspirovaly pasáže z románu Jeana Bédarda. Viz Bédard, J.: Komenský. Labyrint srdce a peklo světa., Jota, Brno 2005, zejména str. 208 a násl.

79 „Pro mysl je nejvyšším dobrem poznání Boha..." Spinoza, B.: Etika, cit. vyd., str. 287.

80 Viz Trlifajová, K.: Teologické predpoklady vzniku Cantorovy teorie množin, 2003, str. 8 a násl. Cit. dle internetových stránek.

81 Připomněl toto tradiční (středověké) rozlišování natura naturans a natura naturata jak ve své Etice, tak i Krátkém pojednání o Bohu, člověku a jeho blahu.

${ }^{82}$ Viz poznámku č. 26.

${ }^{83}$ Viz poznámku č. 28.

${ }^{84}$ Viz poznámky čís. 34 -36. 


\section{E-LOGOS}

\section{ELECTRONIC JOURNAL FOR PHILOSOPHY}

Ročník/Year: 2014 (vychází průběžně/ published continuously)

Místo vydání/Place of edition: Praha

ISSN 1211-0442

Vydává/Publisher:

Vysoká škola ekonomická v Praze / University of Economics, Prague

nám. W. Churchilla 4

Czech Republic

13067 Praha 3

IČ: 61384399

Web: http://e-logos.vse.cz

Redakce a technické informace/Editorial staff and technical information:

Miroslav Vacura

vacuram@vse.cz

Redakční rada/Board of editors:

Ladislav Benyovszky (FHS UK Praha, Czech Republic)

Ivan Blecha (FF UP Olomouc, Czech Republic)

Martin Hemelík (VŠP Jihlava, Czech Republic)

Angelo Marocco (Pontifical Athenaeum Regina Apostolorum, Rome, Italy)

Jozef Kelemen (FPF SU Opava, Czech Republic)

Daniel Kroupa (ZU Plzeň, Czech Republic)

Vladimír Kvasnička (FIIT STU Bratislava, Slovak Republic)

Jaroslav Novotný (FHS UK Praha, Czech Republic)

Jakub Novotný (VŠP Jihlava, Czech Republic)

Ján Pavlík (editor-in-chief) (VŠE Praha, Czech Republic)

Karel Pstružina (VŠE Praha, Czech Republic)

Miroslav Vacura (executive editor) (VŠE Praha, Czech Republic) 